慶應義塾大学学術情報リポジトリ

Keio Associated Repository of Academic resouces

\begin{tabular}{|c|l|}
\hline Title & TRADE AND WELFARE IN GENERAL EQUILIBRIUM \\
\hline Sub Title & \\
\hline Author & 大山, 道廣(OHYAMA, MICHIHIRO) \\
\hline Publisher & Keio Economic Society, Keio University \\
\hline Publication year & 1972 \\
\hline Jtitle & Keio economic studies Vol.9, No.2 (1972.) ),p.37- 73 \\
\hline JaLC DOI & \\
\hline Abstract & \\
\hline Notes & \\
\hline Genre & Journal Article \\
\hline URL & $\begin{array}{l}\text { https://koara.lib.keio.ac.jp/xoonips/modules/xoonips/detail.php?koara_id=AA00260492-1972000 } \\
\text { 2-0037 }\end{array}$ \\
\hline
\end{tabular}

慶應義塾大学学術情報リポジトリ(KOARA)に掲載されているコンテンッの著作権は、それぞれの著作者、学会または出版社/発行者に帰属し、その権利は著作権法によって 保護されています。引用にあたっては、著作権法を遵守してご利用ください。

The copyrights of content available on the KeiO Associated Repository of Academic resources (KOARA) belong to the respective authors, academic societies, or publishers/issuers, and these rights are protected by the Japanese Copyright Act. When quoting the content, please follow the Japanese copyright act. 


\title{
TRADE AND WELFARE IN GENERAL EQUILIBRIUM
}

\author{
Mrchiniro OHYAMa
}

\section{TABLE OF CONTENTS}

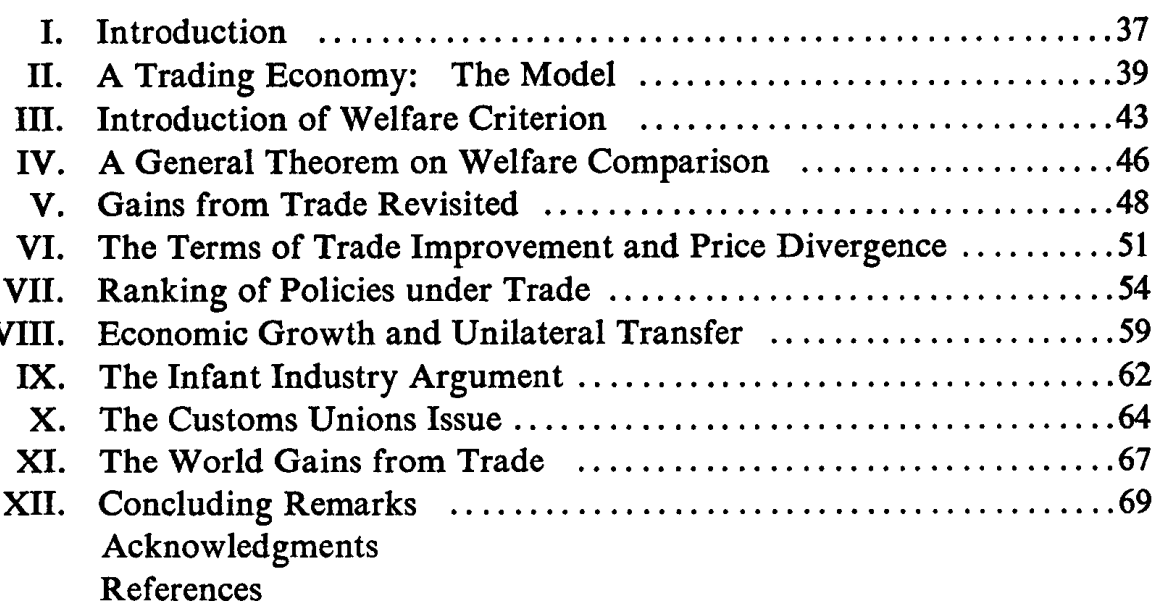

\section{INTRODUCTION}

In his 1939 article, Samuelson initiated the modern discussion of the gains from trade. Concerning himself with a small price-taking country and basing his cases on the compensation principle and the axiom of revealed preference, he established that the introduction of external trade could make all citizens better-off. His approach received a considerable amount of notice, but no further result came of it for some time. It was not until two decades later that Kemp (1962), along with Samuelson (1962), revived the subject by showing, under a more general condition, that the consumption possibility frontier of the post-trade situation lies uniformly outside that of the pre-trade situation. ${ }^{1}$ Their findings, however, seem to call for further generalization.

Meanwhile, trade theorists have propagated the use of the "social indifference" map with the same properties as those of the "individual indifference" map. To substitute for the old tool of numerical example, Leontief (1933) provided a classic employment of this technique in his analysis of trade equilibrium. Scitovsky (1942) and Meade (1952), through their efforts to demonstrate the welfare implications of trade policies, made further contributions

\footnotetext{
${ }^{1} \mathrm{Kemp}$ is concerned with the welfare properties of tariff-restricted trade equilibria (including as a limiting case free trade equilibria), providing a proof of the proposition for a general $n$-commodity case. In a separate companion paper, Samuelson illustrates the same point by the help of the famous "Baldwin" envelope (see Baldwin (1952)) for a special two-commodity case.
} 
to the methodology, and thus stimulated a surge of similar analysis. In the face of this development, Samuelson (1956) reexamined the conditions required to justify the fundamental concept of social indifference. Today, many analysts are more critical than ever of this concept, but its use is still prevalent in the literature on trade and welfare.

Most of the theorists, while employing a social indifference map, assumed no allegiance to any particular map as a matter of course, and thus were, in reality, puristic in their conclusions. The more policy-oriented economists, notably Meade (1955 a, b), often eschewed this nonchalant approach by invoking a specific social utility function. Needless to say, the latter restrictive convention, though objectionable in many respects, makes it possible to evaluate the welfare of all situations without glossing over the underlying social value premises. For instance, per capita real income as a measure of national welfare may be justified on the basis of a very special class of social utility functions. ${ }^{2}$

This paper is devoted to the study of trade and welfare in general equilibrium in which trade in intermediate goods and factor services, as well as the presence of non-tradeable commodities, is not excluded. ${ }^{3}$ For this purpose, we propose to employ a methodological device which captures the results of different approaches in one procedure. In the following section the stage will be set for our analysis by considering a static competitive economy from a single country's viewpoint. We shall define the basic concepts of this paper, such as, an economic situation, distribution, and competitive equilibrium. In section III, there will be the introduction of a welfare criterion, which, with an appropriate reinterpretation, will imply each of the afore-mentioned prototypes. In section IV, a general theorem of welfare comparison will be presented in the form of a simple formula derived from the definition of the country's excess demand, the aggregate budget constraint and the welfare criterion. We shall then make extensive use of this theorem to analyze a number of important issues in trade and welfare. Toward the end of the paper, we will also show that our single country's viewpoint is applicable to a group of countries and

2 We refer here to the crude usage of this measure disregarding the problem of income distribution. We shall have an occasion to discuss it again in Footnote 15.

${ }^{3}$ Most of the existing literature in this field still remains within the confines of the views of "trade-as-exchange-of consumer goods." In a famous survey of trade literature Bhagwati (1964, p. 42) warns that a vast range of interesting problems applicable to economies using intermediate and produced goods, cannot get within the range of analysis until the theorists get away from the traditional picture of primary factors and integrated process of production. As he carefully notes, however, it does not follow that the present stock of knowledge will not survive the required change in the formulation of the models. On the contrary, we should make it clear in advance that our investigation will confirm all the traditional welfare propositions in the presence of trade in non-consumer commodities. 
the world as a whole under appropriate assumptions. Thus, this approach will enable us to generalize familiar theses, and, at the same time, simplify their derivations. It should be noted that, at several points, we will put forward somewhat novel propositions.

\section{A TRADING ECONOMY: THE MODEL}

Let us assume that there are $n$ commodities in the world, some of which are primary factors and intermediate goods. Imagine the competitive economy of a single country engaging in trade with the rest of the world. There are three distinct classes of economic agents, namely producers, consumers, and the government. A producer is supposed to carry out a production plan which is a specification of the quantities of his inputs and outputs. Formally, let $Y^{j}$ be the production set of the $j$ th producer, which is closed in the $n$-dimensional commodity space and contains the origin. We assume thta it is possible for all producers together to dispose of all commodities. A consumers is supposed to carry out a consumption plan which is a specification of his consumption of commodities. A consumption plan is made subject to the constraint of the consumer's income composed of the value of his endowment of commodities, his share in producers' profits and his net transfer receipt. Let $X^{k}$ be the $k$ th consumer's consumption set, which is closed, convex and bounded below in the non-negative orthant of the $n$-dimensional commodity space. The set $X^{k}$ is assumed to be completely pre-ordered by the $k$ th consumer's preference relation (denoted by $z^{k}$ ). No consumer is satiated in all commodities. We abstract from transportation costs and static external economies and diseconomies.

The role of the government, the third class of our economic agent, is manifold. First, it is assumed to tax and/or subsidize various economic activities, i.e., production, consumption and external trade. Secondly, it distributes income among consumers in a lump-sum fashion by changing the structure of individual shares in all income sources. For this purpose, the government is. able to impose personal tax-subsidy schemes on incomes derived from the ownership of commodity endowment, the share in profits, and the net private transfer receipt. The government's net revenue (or cost) from all the taxes and subsidies is assumed to be disposed of by lump-sum transfers to consumers to help achieve the purpose of income redistribution. ${ }^{4}$ Thirdly, the government carries out the production and consumption of commodities on its own. In this capacity, it is assumed to belong to the first two classes of economic

\footnotetext{
4 The government's lump-sum taxes and subsidies are exempt from the distortion of price system since they effectuate nothing but the direct redistribution of income sources such as commodity endowment, profits and transfer receipt among individual consumers.
} 
agents, i.e., producers and consumers. Together with the absence of externalities, this simplifies the problem of public production and consumption. We shall discuss this point briefly at the end of the paper. ${ }^{5}$

Let us now turn our eyes to the aggregate picture of our trading economy. We use the following basic notation:

$x$, a non-negative $n$-vector of aggregate consumption.

$y$, an $n$-vector of aggregate production; a positive (resp. negative) component denotes output (resp. input).

$a$, a non-negative $n$-vector of aggregate endowment exogenously available to the country.

$e \equiv x-y-a$, an $n$-vector of aggregate excess demand.

$q$, a non-negative $n$-vector of world price.

$p$, a non-negative $n$-vector of domestic price.

$p_{c}$ a non-negative $n$-vector of domestic consumers' price.

$p_{r}$ a non-negative $n$-vector of domestic producers' price. ${ }^{6}$

$b$, a scalar denoting net aggregate transfer from abroad to consumers.

$Y \equiv \sum_{j} Y^{j}$, the set of all possible $y$.

$T$, an $n \times n$ diagonal matrix of ad valorem rates of tariffs (i.e., taxes or subsidies on imports and exports).

$C$, an $n \times n$ diagonal matrix of ad valorem rates of taxes or subsidies on consumption.

$R$, an $n \times n$ diagonal matrix of ad valorem rates of taxes or subsidies on production.

The model allows for the existence of non-tradeable commodities due to the international difference of tastes. If commodity $i$ happens to be non-tradeable, then the $i$ th component of vector $e$ is identically zero. Similarly, if commodity $i$ is not consumed at home, the $i$ th component of $x$ is identically zero, and if commodity $i$ is not produced at home, the $i$ th component of $y$ is non-positive. Note also that we take into account the consumers' use of primary factors, especially in the form of leisure. ${ }^{7}$

It is important to understand the relationships between the four different price vectors, $q, p, p_{c}$, and $p_{r}$, pertaining to the economy under trade with the rest of the world. Needless to say, this difference arises in the presence of the governmental intervention in the private transactions via taxes and sub-

${ }^{5}$ For an alternative treatment of public production and consumption, see Diamond and Mirrlees (1971).

6 We will consider $x, y, a$ and $e$ as column vectors, and $p$ and $q$ as row vectors in what follows.

7 Thus, this model includes as a special case the classical setup in which primary factors, especially labor, is not tradeable. 
sidies. ${ }^{8} \quad$ Let us denote by $t_{i}$ the $i$ th diagonal element of tariff matrix $T$, and by $q_{i}$ and $p_{i}$ the $i$ th components of $q$ and $p$ respectively. We have then the arbitrage relationship

$$
p_{i}=q_{i}\left(1+t_{i}\right) \text {. }
$$

If $t_{i}$ is positive, it represents an import tax or an export subsidy depending on whether commodity $i$ is imported or exported. If $t_{i}$ is negative, it represents an export tax or an import subsidy. We can rewrite this relationship in matrix form as

$$
p=q(I+T)
$$

where $I$ is an identity matrix. Likewise, we have

$$
\begin{aligned}
& p_{c}=p(I+C) \\
& p_{r}=p(I+R)
\end{aligned}
$$

which implicitly define the $i$ th diagonal element $c_{i}$ of matrix $C$ and the $i$ th diagonal element $r_{i}$ of matrix $R$ respectively. If $c_{i}$ is positive (resp. negative), it indicates an tax (resp. a subsidy) on the consumption of commodity $i$. On the other hand, if $r_{i}$ is positive (resp. negative), it represents a subsidy (resp. tax) on the production, or a tax (resp. subsidy) on the use in production, of commodity $i$ depending on whether commodity $i$ is an output or an input in the aggregate production process.

To delineate the posture of the economy completely, it is also necessary to take account of the external conditions with which the economy is faced. The net aggregate income transfer $b$ stands for the country's net receipt of purchasing power from abroad available in the form of reparation, aid, personal remittance, and the like. In addition to this, we need to introduce here the concept of the "foreign environment" as a catchall terminology representing the state of technologies, tastes, commodity endowments, and the governmental policies in the rest of the world. In a limiting case in which the country is too small to affect the world market significantly, the foreign environment can be approximated by the prevailing world price of tradeable commodities. We refer to this special case as the state of a price-taking country without any monopoly power in world trade. In another limiting case in which the country keeps to itself in autarky, the specification of the foreign environment is still possible, but evidently irrelevant.

Definition (economic situation): An economic situation (or simply situation) $S$ is a specification of the followings.

\footnotetext{
${ }^{8}$ We assume that the unit of domestic currency is adjusted such that the exchange rate is always unity.
} 
(i) the set of producers: $Y^{j}$ for all $j$;

(ii) the set of consumers: $\left(X^{k}, z^{k}\right)$ for all $k$;

(iii) the government's taxes and subsidies: $(T, C, R)$;

(iv) the aggregate endowment and net income transfer: $(a, b)$;

(v) the foreign environment.

Definition (distribution): A distribution $V$ is a specification of the percentage share of individual consumers in all income sources. ${ }^{9}$

Given an economic situations $S$ and a distribution $V$, we assume the existence of a (usual) competitive equilibrium such that, under the prevailing prices, (a) each producer maximizes his profits over his production set; (b) each consumer maximizes his satisfaction over his budget set; and (c) all markets are cleared. ${ }^{10}$ To write out these conditions of an equilibrium, let a bar on top of a vector indicate its equilibrium value. First of all, we write the equilibrium condition for producers as

$$
\bar{p}_{r} \bar{y}^{j} \geqq \bar{p}_{r} y^{j} \quad \text { for all } \quad y^{j} \in Y^{j}
$$

where $y^{j}$ is the $j$ th producer's production vector. This implies the aggregate profit maximization condition

$$
\bar{p}_{r} \bar{y} \geqq \bar{p}_{r} y \quad \text { for all } \quad y \in Y .
$$

Secondly, the equilibrium condition for cunsumers runs as

$$
\bar{x}^{k} \succsim^{k} x^{k} \quad \text { for all } \quad x^{k} \in X^{k} \quad \text { such that } \quad \bar{p}_{c} \bar{x}^{k} \geqq \bar{p}_{c} x^{k}
$$

where $x^{k}$ is the $k$ th consumer's consumption vector. Finally, in an autarkic situation, we have

$$
\bar{e} \leqq 0 ; \quad \bar{p} \bar{e}=0
$$

for any distribution. In an open-economy situation, we simply have

$$
\bar{q} \bar{e}=b
$$

for any distribution. As a result of free-disposability and non-satiation, we may take all equilibrium vectors to be semi-positive. Condition (6) shows the market clearance in an autarkic situation. Some components of $\bar{e}$ in (6) may be negative as some commodities may be supplied in surplus. On the

9 Thus, if prices are given, a distribution $V$ is a specification of the percentage share of individual consumers in the aggregate expenditure, and it can be represented by an interior point of the standard simplex.

${ }^{10}$ In particular, we have in mind an economy similar to the Arrow-Debreu model for the existence of competitive equilibria. See, e.g. Debreu (1959) and Nikaidô (1968, Chapter 5). McKenzie (1959) allows for negative equilibrium prices, the possibility of which we exclude by assumption in this paper. The demonstration of an existence theorem is, however, out of the scope of the present analysis. The reader interested in this line of inquiry in the cotext of the present model is referred to Sontheimer (1971). 
other hand, condition $\left(6^{\prime}\right)$ represents the aggregate budget constraint of consumers in an open-economy situation. A positive (resp. negative) component of $\bar{e}$ in (6') represents the import (resp. export) of a commodity.

\section{INTRODUCTION OF WELFARE CRITERION}

The stage is now set to discuss the fundamentals of the present study. To initiate the argument, consider two distinct situations, $S^{\prime}$ and $S^{\prime \prime}$, say. Evidently, situation $S^{\prime}$ can be distinct from situation $S^{\prime \prime}$ in many different ways. We shall assume, however, that the set of consumers is given and invariant between the two situations. This implies, among other things, that the set of consumers can be independent of the other elements of economic situation such as the government's taxes and subsidies, the foreign environment, etc. ${ }^{11}$ With this assumption on hand, we wish to compare, from consumers' viewpoint, the welfare of the two situations $S^{\prime}$ and $S^{\prime \prime}$. For this purpose, a brief detour is first necessary to pronounce on the criterion under which we plan to carry out the comparison.

Let us indicate the equilibrium vectors and other symbols relating to $S^{\prime}$ by single primes, and those relating to $S^{\prime \prime}$ by double primes, and, henceforth, omit bars on equilibrium vectors. Let $E(S ; V)$ be the set of tuples of equilibrium vectors $\left(p_{c}, x, \ldots\right)$ for a situation $S$ and a distribution $V$.

Definition (welfare criterion): Situation $S^{\prime \prime}$ is said to be preferable to situation $S^{\prime}$ if condition $p_{c}^{\prime \prime} x^{\prime \prime} \geqq p_{c}^{\prime \prime} x^{\prime}$ is satisfied for all tuples $\left(p_{c}^{\prime}, x^{\prime}, \ldots\right) \in$ $E\left(S^{\prime} ; V^{\prime}\right),\left(p_{c}^{\prime \prime}, x^{\prime \prime}, \ldots\right) \in E\left(S^{\prime \prime} ; V^{\prime \prime}\right)$, and for all relevant distributions $V^{\prime}$ and $V^{\prime \prime} \cdot{ }^{12}$

In a similar vein, the transition from situation $S^{\prime}$ to situation $S^{\prime \prime}$ will be occasionally said to be beneficial, and the reverse transition harmful under the same condition. Thus, a policy change, say, is beneficial if it brings about an increase (or at worst non-decrease) in the aggregate real income in the socalled Paache backward index measure for all relevant distributions.

Caveats are in order concerning the scope of all relevant situations. Needless to say, the relative desirability of a distribution for any situation can only be determined by the specification of one firm or another of social value judge-

11 It should be understood that some trade in labor is in no way at variance with the given set of consumers. At the present level of abstraction, we should be ready to account for the possibility that some kind of labor is traded internationally without affecting the set of consumers and the country's endowment of leisure. For example, some laborers are able to offer their services for a foreign firm located inside the country.

${ }^{12}$ Note that the supply of primary factors is already taken care of in the expression $p_{c}{ }^{\prime \prime} x^{\prime \prime} \geqq$ $p_{c}^{\prime \prime} x^{\prime}$ since individual consumption sets are defined over the exhaustive $n$-dimensional commodity space. 
ment involving the interpersonal comparison of utility. Thus, in the absence of such a specification, we must identify the set of relevant distributions with the set of all potentially feasible distributions. In this case, our definition is equivalent to the conventional Samuelson-Kennedy criterion.

Lemma 1: Let $p_{c}^{\prime \prime} x^{\prime \prime} \geqq p_{c}^{\prime \prime} x^{\prime}$ for all tuples $\left(p_{c}^{\prime}, x^{\prime}, \ldots\right) \in E\left(S^{\prime} ; V^{\prime}\right), \quad\left(p_{c}^{\prime \prime}\right.$, $\left.x^{\prime \prime}, \ldots\right) \in E\left(S^{\prime \prime} ; V^{\prime \prime}\right)$ and for all feasible distributions $V^{\prime}$ and $V^{\prime \prime}$. Then, given any distribution $V^{\prime}$ (resp. $\left.V^{\prime \prime}\right)$, there can be no distribution $V^{\prime \prime}$ (resp. $V^{\prime}$ ) such that some are strictly better-off, while others are not worse-off, in situation $S^{\prime}$ than they are in situation $S^{\prime \prime} .^{13}$

Proof: Consider a partition of the set of indices $K$ of all consumers into two non-emply subsets $K_{1}$ and $K_{2}$ such that, for some distributions $V^{\prime}$ and $V^{\prime \prime}$,

and

$$
x^{k_{1}^{\prime}} \succsim^{k_{1}} x^{k_{1}^{\prime \prime}} \quad \text { for } \quad k_{1} \in K_{1}
$$

$$
x^{k_{2}^{\prime}} \succ^{k_{2}} x_{2}^{k_{2}^{\prime \prime}} \quad \text { for } k_{2} \in K_{2},
$$

where $x^{k^{\prime}}$ (resp. $x^{k^{\prime \prime}}$ ) is an equilibrium consumption vector chosen by the $k$ th consumer in situation $S^{\prime}$ (resp. $S^{\prime \prime}$ ). Then, from (5), we must have

and

$$
p_{c}^{\prime \prime} x_{1}^{k_{1}^{\prime \prime}} \leqq p_{c}^{\prime \prime} x^{k_{1}^{\prime}} \quad \text { for } \quad k_{1} \in K_{1},
$$

$$
p_{c}^{\prime \prime} x_{2}^{k_{2}^{\prime \prime}}<p_{c}^{\prime \prime} x_{2}^{k_{2}^{\prime}} \quad \text { for } \quad h_{2} \in K_{2} \text {. }
$$

(Otherwise, the choice of $x^{k \prime}$ would be contradicted.) But this implies

or

$$
\sum_{k \in K} p_{c}^{\prime \prime} x^{k^{\prime \prime}}<\sum_{k \in K} p_{c}^{\prime \prime} x^{k^{\prime}}
$$

$$
p_{c}^{\prime \prime} x^{\prime \prime}<p_{c}^{\prime \prime} x^{\prime},
$$

which contradicts the hypothesis. ||

The message is somewhat unsatisfactory in light of the compensation principle. Under the same condition, one may wish to establish the unambiguous proposition that, given any feasible distribution $V^{\prime}$, there exists a feasible distribution $V^{\prime \prime}$ such that none is worse-off in situation $S^{\prime \prime}$ than in situation $S^{\prime}$. The latter proposition is certainly true in the special case in which all consumers have identical tastes and identical shares in all income sources as the only feasible distribution. In general, however, we cannot make this point without investigating the problem of the existence of competitive equilibrium which lies outside the scope of the present study. ${ }^{14}$

Alternatively, it is often assumed that there exists a certain social value judgement ordering the set of feasible distribution for each situation, and that the government redistributes income accordingly so as to achieve a best feasible

13 This result is first observed by Samuelson (1950) and later generalized by Kennedy (1954). Kemp (1962) employs essentially the same reasoning in his discussion of gains from trade. 
distribution. In this case, the set of relevant distribution reduces to the set of best feasible distributions. Thus, if the set of feasible distribution $V^{\prime \prime}$ contains the set of feasible distribution $V^{\prime}$, the condition given in our definition of welfare criterion evidently implies the non-deterioration of social welfare as a result of the transition from situation $S^{\prime}$ to situation $S^{\prime \prime}$. It is, however, only under some further assumptions that the use of a well-behaved social indifference map is known to be legitimate. Once we assume the existence of a social indifference map, we are able to abstract from individual consumers and concern ourselves only with the social consumption set $X$ which is convex and completely pre-ordered by a social preference relation (denoted by $z$ ). Relevant distribution $V$ is then uniquely determined for each situation $S$, and the set of consumers is represented simply by the consumption set and preference relation, $(X ; \succsim){ }^{15}$ In this context, it is worthwhile to call attention to a possible property of preference relation $\gtrsim$ and its implications.

Definition (convexity of preference relation): Preference relation $z$ is said to be strongly convex if $x^{\prime \prime} \succsim x^{\prime}$ for distinct $x^{\prime}, x^{\prime \prime} \in X$ implies $\lambda x^{\prime \prime}+$ $(1-\lambda) x^{\prime}>x^{\prime}(0<\lambda<1){ }^{16}$

LEMMA 2: Suppose that preference relation $\gtrsim i$ strongly convex. Then, $p_{c}^{\prime \prime} x^{\prime \prime} \geqq$ $p_{c}^{\prime \prime} x^{\prime}$ implies $x^{\prime \prime} \succ x^{\prime}$, where $x^{\prime}$ (resp. $\left.x^{\prime \prime}\right)$ is an equilibrium aggregate consumption vector in situation $S^{\prime}$ (resp. $\left.S^{\prime \prime}\right)$.

${ }^{14}$ One may, however, proceed in the desired direction as follows. Given $\left(p_{c}{ }^{\prime}, x^{\prime}, \ldots\right) \in$ $E\left(S^{\prime} ; V^{\prime}\right)$, show that it is possible to achieve a distribution $V^{\prime \prime}$ for situation $S^{\prime \prime}$ such that

$$
p_{c}^{\prime \prime} x^{k^{\prime \prime}}=\left(p_{c}{ }^{\prime \prime} x^{k} / p_{c}^{\prime \prime} x^{\prime}\right) p_{c}^{\prime \prime} x^{\prime \prime}
$$

where $\left(p_{c}^{\prime \prime}, x^{\prime \prime}, \ldots\right) \in E\left(S^{\prime \prime} ; V^{\prime \prime}\right)$. Then, $p_{c}^{\prime \prime} x^{\prime \prime} \geqq p_{c}{ }^{\prime \prime} x^{\prime}$ implies

$$
\boldsymbol{p}_{c}^{\prime \prime} x^{k^{\prime \prime}} \geqq\left(\boldsymbol{p}_{c}^{\prime \prime} x^{k^{\prime}} / \boldsymbol{p}_{c}^{\prime \prime} x^{\prime}\right) \boldsymbol{p}_{c}^{\prime \prime} x^{\prime}=\boldsymbol{p}_{c}^{\prime \prime} x^{k^{\prime}} \text {. }
$$

Thus, from (5), we obtain $x^{k^{\prime \prime}} \gtrsim^{k} x^{k^{\prime}}$.

${ }^{15}$ See Samuelson (1956) and Negishi (1965). Chipman (1965) gives an extensive survey of the retated literature. Consider a limiting case where there is an additive social utility function with every consumer possessing an identical, linear homogeneous utility function. Write the social utility as

$$
F\left(p_{c}\right)=\sum_{k \in K} u\left(x^{k}\left(p_{c}\right)\right)
$$

where $u$ denotes the utility function common to all consumers and $x^{k}\left(p_{c}\right)$ the consumption vector chosen by the $k$ th consumer at price $p_{c}$. Since $\mathrm{u}$ is linear-homogeneous, we obtain

$$
F\left(p_{c}\right)=u\left(x\left(p_{c}\right)\right) \quad \text { where } \quad x\left(p_{c}\right)=\sum_{k \in K} x^{k}\left(p_{c}\right) .
$$

At each price $p_{c}, u\left(p_{c}\right)$ is maximized over the set of the aggregate consumption vectors $x$ such that $p_{c} x \leqq p_{c} x\left(p_{c}\right)$. In this case, we have a social indifference map regardless of the state of distribution. In fact, all distributions are deemed equally good. Thus, our welfare criterion degenerates to the crude convention of measuring social welfare in terms of per capita real income with no reference to distribution.

${ }^{16}$ For a discussion of convex preference relation, see, for example, Debreu (1959), pp. 59-61. 
Proof: To the contrary, suppose $x^{\prime} \approx x^{\prime \prime}$. Then, by the strong convexity of $\approx$, we have $\lambda x^{\prime}+(1-\lambda) x^{\prime \prime}>x^{\prime \prime}(0<\lambda<1)$, where $\lambda x^{\prime}+(1-\lambda) x^{\prime \prime} \in X$ by the convexity of $X$. But $p_{c}^{\prime \prime} x^{\prime \prime} \geqq p_{c}^{\prime \prime} x^{\prime}$ implies $p_{c}^{\prime \prime} x^{\prime \prime} \geqq p_{c}^{\prime \prime}\left[\lambda x^{\prime}+(1-\lambda) x^{\prime \prime}\right]$ thereby contradicting the choice of $x^{\prime \prime}$ (see (5)). 11

Thus, if a social indifference map is assumed to exist with surfaces strictly convex toward the origin, our welfare criterion can be seen to give a sufficient (but by no means necessary) condition for a strict increase of social welfare from situation $S^{\prime}$ to situation $S^{\prime \prime}$. This conclusion may also be extended to the economy with non-consumable commodities provided that preference relation is strongly convex in the space of consumable commodities, and that there is no surplus in the supply of non-consumable commodities. In any case, it is vital to bear the above result in mind in interpreting the forthcoming propositions in proper relation to the traditional analyses of trade and welfare.

\section{A GENERAL THEOREM ON WELFARE COMPARISON}

Leaving the discussion of welfare criterion, let us now turn to the central theme of this study. To avoid unnecessary repetition of similar reasoning, we wish to provide here a general theorem of welfare comparison focusing upon a basic formula comparing the welfare of two situations $S^{\prime}$ and $S^{\prime \prime}$. Simple as it is, the formula contains most of the important recults in the area with which we are concerned, and will serve as a cornerstone of the subsequent analyses.

Suppose that $S^{\prime \prime}$ represents a situation under trade. Our strategy is to break down into several meaningful constituents the expression $p_{c}^{\prime \prime}\left(x^{\prime \prime}-x^{\prime}\right)$, i.e., the change in the aggregate real income in the Paache sense involved in the transition from situation $S^{\prime}$ to situation $S^{\prime \prime}$. To carry this out, first recall the definition of excess demand:

$$
e=x-y-a \text {. }
$$

Applying equations (1), (2), and (3) to situation $S^{\prime \prime}$, we get

$$
\begin{aligned}
& p_{c}^{\prime \prime}=q^{\prime \prime}\left(I+T^{\prime \prime}\right)\left(I+C^{\prime \prime}\right) ; \\
& p_{r}^{\prime \prime}=q^{\prime \prime}\left(I+T^{\prime \prime}\right)\left(I+R^{\prime \prime}\right) .
\end{aligned}
$$

From (7) and (8), we are able to write

$$
\begin{aligned}
p_{c}^{\prime \prime}\left(x^{\prime \prime}-x^{\prime}\right)= & q^{\prime \prime}\left(I+T^{\prime \prime}\right)\left(I+C^{\prime \prime}\right)\left\{\left(e^{\prime \prime}+y^{\prime \prime}+a^{\prime \prime}\right)-\left(e^{\prime}+y^{\prime}+a^{\prime}\right)\right\} \\
= & q^{\prime \prime}\left(e^{\prime \prime}-e^{\prime}\right)+q^{\prime \prime} T^{\prime \prime}\left(e^{\prime \prime}-e^{\prime}\right)+q^{\prime \prime}\left(I+T^{\prime \prime}\right) C^{\prime \prime}\left(x^{\prime \prime}-x^{\prime}\right) \\
& +q^{\prime \prime}\left(I+T^{\prime \prime}\right)\left\{\left(y^{\prime \prime}-y^{\prime}\right)+\left(a^{\prime \prime}-a^{\prime}\right)\right\} .
\end{aligned}
$$

In light of (1), (2), and (9), we find 


$$
q^{\prime \prime}\left(I+T^{\prime \prime}\right)=p^{\prime \prime}=p_{r}^{\prime \prime}-p^{\prime \prime} R^{\prime \prime}
$$

Substituting (11) into (10), we obtain the desired decomposition as follows:

$$
\begin{aligned}
p_{c}^{\prime \prime}\left(x^{\prime \prime}-x^{\prime}\right)= & q^{\prime \prime}\left(e^{\prime \prime}-e^{\prime}\right)+q^{\prime \prime} T^{\prime \prime}\left(e^{\prime \prime}-e^{\prime}\right)+p^{\prime \prime} C^{\prime \prime}\left(x^{\prime \prime}-x^{\prime}\right) \\
& +p^{\prime \prime} R^{\prime \prime}\left(y^{\prime}-y^{\prime \prime}\right)+p_{r}^{\prime \prime}\left(y^{\prime \prime}-y^{\prime}\right)+p^{\prime \prime}\left(a^{\prime \prime}-a^{\prime}\right)
\end{aligned}
$$

THEOREM 1: If condition

$$
\begin{aligned}
q^{\prime \prime}\left(e^{\prime \prime}-e^{\prime}\right)+ & q^{\prime \prime} T^{\prime \prime}\left(e^{\prime \prime}-e^{\prime}\right)+p^{\prime \prime} C^{\prime \prime}\left(x^{\prime \prime}-x^{\prime}\right) \\
& +p^{\prime \prime} R^{\prime \prime}\left(y^{\prime}-y^{\prime \prime}\right)+p_{r}^{\prime \prime}\left(y^{\prime \prime}-y^{\prime}\right)+p^{\prime \prime}\left(a^{\prime \prime}-a^{\prime}\right) \geqq 0
\end{aligned}
$$

is satisfied for all tuples $\left(p_{c}^{\prime}, x^{\prime}, \ldots\right) \in E\left(S^{\prime} ; V^{\prime}\right),\left(p_{c}^{\prime \prime}, x^{\prime \prime}, \ldots\right) \in E\left(S^{\prime \prime} ; V^{\prime \prime}\right)$, and for all relevant distributions $V^{\prime}$ and $V^{\prime \prime}$, situation $S^{\prime \prime}$ is preferable to situation $S^{\prime}$.

Proof: Straightforward from the definition of welfare criterion and equation (12). ||

Each term in condition (13) can be interpreted as a component of the real income change in the Paache sense. Thus, the term $q^{\prime \prime}\left(e^{\prime \prime}-e^{\prime}\right)$, if positive, shows the gain in the trade deficit from situation $S^{\prime}$ to situation $S^{\prime \prime}$ if world prices remain unchanged, or $q^{\prime}=q^{\prime \prime}$. Likewise, the terms $q^{\prime \prime} T^{\prime \prime}\left(e^{\prime \prime}-e^{\prime}\right)$, $p^{\prime \prime} C^{\prime \prime}\left(x^{\prime \prime}-x^{\prime}\right)$ and $p^{\prime \prime} R^{\prime \prime}\left(y^{\prime}-y^{\prime \prime}\right)$ indicate in turn the gain in the government's net revenue arising from tariffs, taxes and subsidies on consumption, and taxes and subsidies on production on the assumption that $q^{\prime}=q^{\prime \prime}, p^{\prime}=p^{\prime \prime}, C^{\prime}=C^{\prime \prime}$ and $R^{\prime}=R^{\prime \prime}$. The terms $p_{r}^{\prime \prime}\left(y^{\prime \prime}-y^{\prime}\right)$ and $p^{\prime \prime}\left(a^{\prime \prime}-a^{\prime}\right)$ show respectively the gain in producers' profits and the income from endowment if $p^{\prime}=p^{\prime \prime}$ and $p_{r}^{\prime}=p_{r}^{\prime \prime}$.

The lengthy expression of condition (13) may obscure its intrinsic usefulness for analytical purposes. In what follows, however, we shall often (but not always) assume that the set of producers and the aggregate endowment are constant between situations $S^{\prime}$ and $S^{\prime \prime} .{ }^{17} \quad$ This implies

$$
a^{\prime}=a^{\prime \prime} ; \quad Y^{\prime}=Y^{\prime \prime} .
$$

Under this assumption, the profit maximization condition (4) implies

$$
p_{r}^{\prime \prime}\left(y^{\prime \prime}-y^{\prime}\right)+p^{\prime \prime}\left(a^{\prime \prime}-a^{\prime}\right)=p_{r}^{\prime \prime}\left(y^{\prime \prime}-y^{\prime}\right) \geqq 0 \text {. }
$$

Furthermore, we shall examine the effect of tariffs and other kinds of taxes and subsidies in isolation to focus upon its feature in sharp relief. Therefore, it will be convenient to have the simplified version of the previous theorem on hand.

Theorem 2: Assume that $a^{\prime}=a^{\prime \prime}$ and $Y^{\prime}=Y^{\prime \prime}$. (i) Let $C^{\prime \prime}=R^{\prime \prime}=0$. Then, if condition

\footnotetext{
17 Again, this should not be regarded as inconsistent with trade in primary factors.
} 


$$
q^{\prime \prime}\left(e^{\prime \prime}-e^{\prime}\right)+q^{\prime \prime} T^{\prime \prime}\left(e^{\prime \prime}-e^{\prime}\right) \geqq 0
$$

is satisfied, situation $S^{\prime \prime}$ is preferable to situation $S^{\prime}$. (ii) Let $T^{\prime \prime}=R^{\prime \prime}=0$. Then, if condition

$$
q^{\prime \prime}\left(e^{\prime \prime}-e^{\prime}\right)+p^{\prime \prime} C^{\prime \prime}\left(x^{\prime \prime}-x^{\prime}\right) \geqq 0
$$

is satisfied, situation $S^{\prime \prime}$ is preferable to situation $S^{\prime}$. (iii) Let $T^{\prime \prime}=C^{\prime \prime}=0$. Then, if condition

$$
q^{\prime \prime}\left(e^{\prime \prime}-e^{\prime}\right)+p^{\prime \prime} R^{\prime \prime}\left(y^{\prime}-y^{\prime \prime}\right) \geqq 0
$$

is satisfied, situation $S^{\prime \prime}$ is preferable to situation $\boldsymbol{S}^{\prime}$.

Proof: Straightforward from Theorem 1 and (14). ||

Note that, in the statement of Theorem 2, we have tacitly avoided the complete enumeration of conditions as found in Theorem 1. In order to alleviate scholastic wordiness, we shall follow this convention hereafter in the belief that no confusion is thereby incurred.

Now, suppose that $S^{\prime}$, as well as $S^{\prime \prime}$, represents an open-economy situation. By virtue of $\left(6^{\prime}\right)$, we can then write

$$
q^{\prime \prime}\left(e^{\prime \prime}-e^{\prime}\right)=\left(b^{\prime \prime}-b^{\prime}\right)+\left(q^{\prime}-q^{\prime \prime}\right) e^{\prime}
$$

where the term $\left(b^{\prime \prime}-b^{\prime}\right)$ indicates the gain in the net aggregate transfer from abroad, and the term $\left(q^{\prime}-q^{\prime \prime}\right) e^{\prime}$ the terms of trade improvement in the Laspeyres sense, from situation $S^{\prime}$ to situation $S^{\prime \prime} .{ }^{18} \quad$ In this case, we are able to rewrite condition (13) accordingly. In particular, conditions (15)-(17) become

$$
\begin{aligned}
& \left(b^{\prime \prime}-b^{\prime}\right)+\left(q^{\prime}-q^{\prime \prime}\right) e^{\prime}+q^{\prime \prime} T^{\prime \prime}\left(e^{\prime \prime}-e^{\prime}\right) \geqq 0 ; \\
& \left(b^{\prime \prime}-b^{\prime}\right)+\left(q^{\prime}-q^{\prime \prime}\right) e^{\prime}+p^{\prime \prime} C^{\prime \prime}\left(x^{\prime \prime}-x^{\prime}\right) \geqq 0 ; \\
& \left(b^{\prime \prime}-b^{\prime}\right)+\left(q^{\prime}-q^{\prime \prime}\right) e^{\prime}+p^{\prime \prime} R^{\prime \prime}\left(y^{\prime}-y^{\prime \prime}\right) \geqq 0 .
\end{aligned}
$$

We shall discuss in detail the more important economic implications of these results in the following pages.

\section{THE GAINS FROM TRADE REVISITED}

Some trade is preferable to no trade. Although this is one of the most familiar dicta in economics, one must be careful about the exact bearing of the adjective "some". For instance, Bhagwati (1968 a) elucidates a distinction between trade restricted by tariffs and trade restricted by taxes and subsidies on domestic consumption and production. Let us start out by restating the

${ }^{18}$ Note that if the price of an export (resp. import) commodity increases (resp. decreases) from situation $S^{\prime}$ to situation $S^{\prime \prime}$, the term $\left(q^{\prime}-q^{\prime \prime}\right) e^{\prime}$ will have to be, ceteris paribus, positive. 
celebrated theorem, originally formalized by Kemp (1962) and Samuelson (1962). We use

Definition (free trade): Free trade is an open economy situation with neither tariffs nor domestic taxes and subsidies, i.e. $T=C=R=0$.

With this in mind, we are able to state

Proposition 1: (i) Free trade is preferable to no trade. (ii) Trade restricted by taxes on imports and/or exports is preferable to no trade..$^{19}$

But we can in fact establish a more general proposition which applies to trade under tariffs comprising subsidies as well as taxes. Let us introduce

Definition (self-financing tariffs): Tariffs are said to be self-financing if the net tariff revenue is non-negative.

Needless to say, there are self-financing tariffs when trade subsidies are virtually financed out of the proceeds from trade taxes. To isolate the gains from trade, we assume that the net aggregate transfer is null.

Proposition 2: Trade under self-financing tariffs is preferable to no trade.

Proof: We identify no trade with situation $S^{\prime}$ and trade under self-financing tariffs with situation $S^{\prime \prime}$ in Theorem 2-(i). As we assume $b^{\prime \prime}=q^{\prime \prime} e^{\prime \prime}=0$, we can rewrite condition (15) as

$$
q^{\prime \prime} T^{\prime \prime} e^{\prime \prime}-p^{\prime \prime} e^{\prime} \geqq 0
$$

Note that $q^{\prime \prime} T^{\prime \prime} e^{\prime \prime}$ is the net tariff revenue which is assumed to be non-negative. From (6), $e^{\prime} \leqq 0$. Since $p^{\prime \prime} \geqq 0$, condition (15) is satisfied. ||

Proposition 1 follows at once as a corollary. Clearly, the proof remains valid even if some commodities are free and some others are not available in the pre-trade situation. Thus, proposition 2 covers trade arising from "vent for surplus" (see Myint (1958)) as well as trade based upon availabilities (see Kravis (1956)). To our knowledge, this is the most comprehensive result ever obtained on the gains from trade. ${ }^{20}$

Let us turn to trade restricted by taxes and subsidies on consumption or production. It differs from trade restricted by tariffs in that it creates a discrepancy between consumers' price and producers' price in the domestic market. In the words of Bhagwati and Ramaswami (1963), trade restricted by domestic taxes and subsidies brings in perverse distortions along with trade, while trade restricted by tariffs simply opens up the country. This generates a subtle, but definite dissimilarity between the two situations because of the

${ }^{19}$ By the same token, trade restricted by quotas is preferable to no trade. See Kemp (1964), p. 166.

20 Both Kemp and Samuelson avoid the discussion of trade with subsidies. 
fact that consumers' price counts in the ultimate analysis of welfare economics as discussed above (Section III).

Now, let autarky correspond to situation $S^{\prime}$, and trade restricted by domestic taxes and subsidies to situation $S^{\prime \prime}$ in Theorem 2-(ii) or 2-(iii). We then obtain

Proposition 3: If condition

$$
p^{\prime \prime} C^{\prime \prime}\left(x^{\prime \prime}-x^{\prime}\right) \geqq 0
$$

is satisfied, trade restricted by taxes and subsidies on consumption is preferable to no trade.

Proposition 4: If condition

$$
p^{\prime \prime} R^{\prime \prime}\left(y^{\prime}-y^{\prime \prime}\right) \geqq 0
$$

is satisfied, trade restricted by taxes and subsidies on production is preferable to no trade. ${ }^{21}$

The proofs are straightforward from Theorem 2-(ii) or 2-(iii) and omitted here. Concerning Proposition 3, we may presume

$$
c_{i}^{\prime \prime} \geqq 0 \quad \text { if } \quad e_{i}^{\prime \prime}>0 ; \quad c_{i}^{\prime \prime} \leqq 0 \quad \text { if } \quad e_{i}^{\prime \prime}<0
$$

since taxes and subsidies are supposed to restrict trade. Thus, for instance, condition (19) will be satisfied if $x_{i}^{\prime \prime} \geqq x_{i}^{\prime}$ for all $i$ such that $e_{i}^{\prime \prime}>0$, and if $x_{i}^{\prime \prime} \leqq x_{i}^{\prime}$ for all $i$ such that $e_{i}^{\prime \prime}<0$. An interesting special case is the situation in which taxes are levied only on the consumption of foreign luxuries unavailable in autarky. Another less interesting special case is an exchange economy in which production has no role to play. Generally speaking, however, the sign restriction on the matrix $C^{\prime \prime}$ is not sufficient to exclude the possibility that condition (19) fails to hold. A similar conclusion will apply to Proposition 4. To push this point further, Bhagwati (1968 a) constructs examples in which no trade is preferable to trade restricted by domestric tax-subsidy schemes.

Thus, it is not correct to presume that restricted trade is preferable to no trade regardless of the manner of restriction. A fortiori, it is fallacious to say that any trade is preferable to no trade. Consider for example a predatory trade which involves free transfer of national scarce resources. We have ruled this out in this section by assuming the absence of (negative or positive) income transfer to consumers. But we have not thereby eliminated situations not

21 These two propositions correspond to the result of Kemp and Negishi (1970, theorems 3 and 4), which came to our notice after the completion of this study. They interpret conditions (19) and (20) rather narrowly assuming that the same tax-subsidy scheme exists before and after trade. As is clear from the derivation of these conditions, this assumption is not necessary. We can freely identify situation $S^{\prime}$ with any autarkic situation in regard to the domestic taxes and subsidies. 
quite dissimilar to a predatory trade. Take for instance trade saddled with tariffs which are not self-financing. It occurs only if the government finances the net tariff cost by lump-sum taxes, and therefore resembles a combination of trade and negative income transfer. The autarkic situation may well be better than such trade.

\section{THE TERMS OF TRADE IMPROVEMENT AND PRICE DIVERGENCE}

It is a common presumption that the gains from trade will be greater, the more the external prices "diverge" from those of the autarkic state. Samuelson (1939) muses over the problem, but quickly leaves it only asserting that his answer is in the affirmative. Kemp (1964) suggests a useful concept of price divergence; Krueger and Sonnenschein (1967) adopt Kemp's concept to substantiate the price divergence conjecture to some extent; and yet Kemp (1969, p. 266) finally concludes that this speculation is false. In this section, we shall generalize Kemp's definition of price divergence, and argue that the classical conjecture is not entirely unfounded.

We wish, however, first to clarify the welfare implication of the terms of trade improvement. It will turn out to be fundamental to the price divergence thesis. Let $q^{\prime}$ and $q^{\prime \prime}$ be the external price vectors found in two different trading situations, $S^{\prime}$ and $S^{\prime \prime}$. Suppose that there are no tariffs and no domestic taxes and subsidies in both the situations, and that an autonomous improvement of the terms of trade in the Laspeyres sense takes place in the transition from $S^{\prime}$ to $S^{\prime \prime}$ with everything else being unchanged. It is then immediate to reestablish the noted Krueger-Sonnenschen theorem in the present general context.

Proposition 5: If free trade prevails, the terms of trade improvement in the Laspeyres sense is beneficial. ${ }^{22}$

Proof: By hypothesis, Theorem 2 is applicable. Let $T^{\prime \prime}=C^{\prime \prime}=R^{\prime \prime}=0$ and $b^{\prime}=b^{\prime \prime}$. Then, conditions $\left(15^{\prime}\right)-\left(17^{\prime}\right)$ reduce to $\left(q^{\prime}-q^{\prime \prime}\right) e^{\prime} \geqq 0$. As noted above, the terms of trade improvement from $S^{\prime}$ to $S^{\prime \prime}$ means $\left(q^{\prime}-q^{\prime \prime}\right) e^{\prime}>0$, and the condition is satisfied with strict inequality. $\mid 1$

To proceed to a rehabilitation of the price divergence thesis, we want to be able to compare alternative external prices in their relation to the autartic price in an appropriate manner. For this purpose, we propose to normalize all price vectors such that their components add up to unity. This procedure is necessary only for the rest of this section in which we continue to concern

${ }^{22}$ See Krueger and Sonnenschein (1967), pp. 123-124, and also Kemp (1969), pp. 262-265. Our theorem 2 gives a more general result regarding a trading situation with tariffs or other taxes and subsidies. 
ourselves with free trade situations vis-a-vis the autarkic situation. ${ }^{23}$ Let $p^{0}$ be the autarkic price vector. For any external price vector $q$, one can define a diagonal matrix $D$ such that

$$
q=p^{0}(I+D) .
$$

Denoting by $d_{i}$ the $i$ th diagonal entry of $D$, we then have

$$
d_{i}=\left(q_{i}-p_{i}^{0}\right) / p_{i}^{0} .
$$

In the following, we shall associate $D$ (resp. $d_{i}$ ) consistently with $q$ (resp. $q_{i}$ ). For example, we shall write

$$
\begin{aligned}
q^{\prime} & =p^{0}\left(I+D^{\prime}\right), \quad q^{\prime \prime}=p^{0}\left(I+D^{\prime \prime}\right) ; \\
d_{i}^{\prime \prime} & =\left(q_{i}^{\prime}-p_{i}^{0}\right) / p_{i}^{0}, \quad d_{i}^{\prime \prime}=\left(q_{i}^{\prime}-p_{i}^{0}\right) / p_{i}^{0}, \quad \text { etc. }
\end{aligned}
$$

Let us consider

Definition (price divergence): An external price vector $q^{\prime \prime}$ is said to diverge more from the autarkic price vector $p^{0}$ than does $q^{\prime}$ if

(i) $d_{i}^{\prime \prime} \leqq d_{i}^{\prime}$ for all $i$ such that $d_{i}^{\prime}<0$;

(ii) $d_{i}^{\prime \prime} \geqq d_{i}^{\prime}$ for all $i$ such that $d_{i}^{\prime}>0$;

(iii) $d_{i}^{\prime \prime}=d_{i}^{\prime}$ for all $i$ such that $d_{i}^{\prime}=0$

with at least one strict inequality.

This definition seems intuitively natural as a characterization of the notion of price divergence, and contains the concept of $\operatorname{Kemp}(1969$, p. 266) as a special case. According to Kemp, $q^{\prime \prime}$ is said to diverge from $p^{0}$ by more than does $q^{\prime}$ if $q^{\prime \prime}$ can be expressed as a convex combination of $q^{\prime \prime}$ and $p^{0}$, i.e.

$$
q^{\prime}=\lambda q^{\prime \prime}+(1-\lambda) p^{0} \quad(0<\lambda<1) .
$$

Obviously, this condition is satisfied if and only if $\lambda d_{i}^{\prime \prime}=d_{i}^{\prime}$ for all $i$ in our definition.

Given the autarkic price vector $p^{0}$, let us now define a binary relation " $\nu$ " such that $q^{\prime \prime} q^{\prime}$ means " $q$ " is more divergent from $p^{0}$ than is $q^{\prime}$. " One can easily show that the relation " $\nu$ " satisfies transitivity. Given a reference external price vector $q^{0}$ in addition, we may define a set of external prices

$$
Q\left(p^{0}, q^{0}\right)=\left\{q \mid q^{v} q^{0}\right\} \cup\left\{q^{0}\right\} .
$$

For $q \in Q\left(p^{0}, q^{0}\right)$, we introduce the hypothesis.

$$
\begin{array}{lll}
d_{i}<0 & \text { for all } i \text { with } & e_{i}>0 \\
d_{i}>0 & \text { for all } i \text { with } & e_{i}<0
\end{array}
$$

where $e_{i}$ is the $i$ th component of excess demand vector $e$ associated in equilibrium with price vector $q$. This means that the autarkic prices of importables

${ }^{23}$ The price normalization is permissible when we assume away all taxes and subsidies. 
are higher and those of exportables are lower than the corresponding external prices. It also implies

$$
e_{i} \gtrless 0 \text { according as } e_{i}^{0} \gtrless 0
$$

where $e_{i}^{0}$ is the $i$ th component of vector $e^{0}$ associated with the reference price vector $q^{0}$. This means that the import-export pattern remains invariable for all $q \in Q\left(p^{0}, q^{0}\right) .^{24}$ The price divergence conjecture may now be formalized as

Proposition 6: Under hypothesis $(\mathrm{H})$, for any $q^{\prime}, q^{\prime \prime} \in Q\left(p^{0}, q^{0}\right)$ such that $q^{\prime \prime} q^{\prime}$, free trade under price vector $q^{\prime \prime}$ is preferable to free trade under $q^{\prime}$.

Proof: Let $S^{\prime}$ represent free trade under $q^{\prime}$, and $S^{\prime \prime}$ free trade under $q^{\prime \prime}$. By hypothesis, we then have

$$
\begin{array}{ll}
d_{i}^{\prime}-d_{i}^{\prime \prime} \geqq 0 & \text { for all } i \text { such that } \quad e_{i}^{\prime}>0 ; \\
d_{i}^{\prime}-d_{i}^{\prime \prime} \leqq 0 & \text { for all } i \text { such that } \quad e_{i}^{\prime}<0 .
\end{array}
$$

Hence, form (21)

$$
\left(q^{\prime}-q^{\prime \prime}\right) e^{\prime}=p^{0}\left(D^{\prime}-D^{\prime \prime}\right) e^{\prime}>0 .
$$

That is, $q^{\prime \prime}$ represents a terms of trade improvement in relation to $q^{\prime}$, and the desired conclusion follows from Proposition 5. 11

Note that Proposition 6 is stated so as to capture "the greater, the more" property of the price divergence thesis. In fact, we may suppose $q^{\prime \nu} q^{0}$ and conclude that free trade under $q^{\prime}$ is preferable to free trade under $q^{0}$, and that since $q^{\prime \prime \nu} q^{\prime}$, free trade under $q^{\prime \prime}$ is more preferable than free trade under $q^{\prime}$ to free trade under $q^{0}$. In this case, we also note

$$
\left(q^{0}-q^{\prime \prime}\right) e^{0}>\left(q^{0}-q^{\prime}\right) e^{0}>0 .
$$

In words, $q^{\prime \prime}$ means a greater terms of trade improvement over $q^{0}$ then does $q^{\prime}$. The converse of this relationship is, however, generally untenable as illustrated by Krueger and Sonnenschein $(1967$, p. 127). But consider a subset $\bar{Q}$ of $Q\left(p^{0}, q^{0}\right)$ such that either $q^{\prime \nu} q^{\prime \prime}$ or $q^{\prime \prime \nu} q^{\prime}$ must hold for $q^{\prime}, q^{\prime \prime} \in \bar{Q}$. The set $\bar{Q}$ is not empty since, given $p^{0}$ and $q^{\theta}$, one can always find a pair of price vectors for which the specification is satisfied. Now suppose $\left(q^{0}-q^{\prime \prime}\right) e^{0}>$ $\left(q^{0}-q^{\prime}\right) e^{0}$ and $q^{\prime \nu} q^{\prime \prime}$. The former implies

$$
\left(q^{\prime}-q^{\prime \prime}\right) e^{0}>0
$$

\footnotetext{
24 These assumptions are not at all novel in the literature on the pattern of trade. They reflect the doctrine of comparative advantage that a country's pattern of trade is determined by its autarkic cost structure vis-a-vis the external cost structure. As Inada (1967) demonstrates, however, the possibility of locally unique multiple equilibria undermines their intuitive plausibility.
} 
But, under hypothesis $(\mathrm{H})$, the latter implies $q_{i}^{\prime}-q_{i}^{\prime \prime} \leqq 0$ for $e_{i}^{0}>0$ and $q_{i}^{\prime}-q_{i}^{\prime \prime} \geqq 0$ for $e_{i}^{0}<0$ yielding a contradiction. Thus, we can generalize the trasitivity theorem entertained by Krueger and Sonnenschein as follows.

Proposition 7: Given $p^{0}$ and $q^{0}$, and under hypothesis $(\mathrm{H})$, more of the terms of trade improvement is preferable to less of it if brought about by a shift within a subset $\bar{Q}$ of the price set $Q\left(p^{0}, q^{0}\right)$.

To illustrate the purpose of this seemingly pedantic section, let us consider a small country who exports a few primary goods (e.g., tea and textiles), and imports a large number of intermediate goods and factor inputs (e.g., machines and oil) unavailable in the autarkic state. For such a country, the higher the world prices of tea and textiles, or lower those of machines and oil, the greater will be, ceteris paribus, the gains from free trade unambiguously. The country's technology and preference structure are such that it cannot change its obvious import-export pattern under all circumstances. The price divergence thesis is perhaps meant to convey this kind of message, and there is no reason to disregard the grain of truth it carries.

\section{RANKING OF POLICIES UNDER TRADE}

Tariffs and other forms of the government intervention in the economy have furnished one of the most exciting topics for economists. For example, using the two-by-two model of international trade, trade theorists have, rigorously established that, under certain fundamental conditions, an increase in the level of tariffs will improve the country's terms of trade, but will diminish the volume of exports. ${ }^{25}$ In the present study, however, we are not directly concerned with the result of comparative statics per se. Rather, the burden of this section is to derive, from our general theorem, some additional welfare statements regarding ranking of policies under trade.

We compare here two situations under trade which differ from each other only in the government's taxes and subsidies, $(T, C, R)$. Thus, Theorem 2 is applicable with $b^{\prime}=b^{\prime \prime}$, and conditions $\left(15^{\prime}\right)-\left(17^{\prime}\right)$ simplify to

$$
\begin{aligned}
& \left(q^{\prime}-q^{\prime \prime}\right) e^{\prime}+q^{\prime \prime} T^{\prime \prime}\left(e^{\prime \prime}-e^{\prime}\right) \geqq 0 ; \\
& \left(q^{\prime}-q^{\prime \prime}\right) e^{\prime}+p^{\prime \prime} C^{\prime \prime}\left(x^{\prime \prime}-x^{\prime}\right) \geqq 0 ; \\
& \left(q^{\prime}-q^{\prime \prime}\right) e^{\prime}+p^{\prime \prime} R^{\prime \prime}\left(y^{\prime}-y^{\prime \prime}\right) \geqq 0 .
\end{aligned}
$$

To refresh memory, the first term on the left-hand side of each condition represents the terms of trade change occuring in the transition from $S^{\prime}$ to $S^{\prime \prime}$. The second term, on the other hand, expresses the complicated effect of the

${ }^{25}$ See, for example Mundell (1960), pp. 86-90, and Jones (1969). 
change in the volume and composition of trade, consumption, or production. When the change in profits $p_{r}^{\prime \prime}\left(y^{\prime \prime}-y^{\prime}\right)$ is of the second-order magnitude, conditions $\left(15^{\prime \prime}\right)-\left(17^{\prime \prime}\right)$ correspond to the dichotomy of welfare change $a$ la Meade (1955 a).

It is conceivable and often likely that the two effects work in the opposite directions. First consider free trade as situation $S^{\prime}$. The introduction of, say, some protective tariffs may contract the country's volume of trade, but improve the terms of trade. Consider the latter situation with tariffs as situation $S^{\prime \prime}$, and suppose that, in the presence of a well-behaved social indifference map, condition $\left(15^{\prime}\right)$ is satisfied. Then, in view of Theorem 2-(i), the tariffs will be said to be beneficial. Given such tariffs, one may proceed to examine the welfare effect of successive increases (or decreases) in the level of tariffseach time applying Theorem 2-(i) as above-until condition $\left(15^{\prime}\right)$ is no longer tenable. This process of searching for the optimal level of tariffs underlies the reasonings of the MacDougal-Jasay cases for curtailing foreign investment, as well as the Bickerdike-Edgeworth argument for protective tariffs, envisioned in the simpler models of trade. ${ }^{26}$ The same conjecture will also be applied to the restriction of trade by means of taxes and subsidies on domestic consumption or production. ${ }^{27}$

The country may, however, be too small to affect the terms of trade significantly via a change in the government's taxes and subsidies. For simplicity, suppose that the world price of tradeable commodities is completely independent of the country's imports and exports. On this assumption of a pricetaking country, we shall investigate various policy problems for the rest of this section. To start with, consider Kemp's argument (1964) that the lower the level of tariffs, the greater will be the gains from trade in this special case. As Bhagwati (1968) points out, this conclusion is not generally supportable. From Theorem 2-(i), we can instead state

Proposition 8: If condition

$$
q^{\prime \prime} T^{\prime \prime}\left(e^{\prime \prime}-e^{\prime}\right) \geqq 0
$$

is satisfied, a change in tariffs (and the abolition of domestic taxes and subsidies if any) from situation $S^{\prime}$ to situation $S^{\prime \prime}$ is beneficial for a price-taking country.

Proof: Since the world price of tradeable commodities is constant, we have $q^{\prime} e^{\prime}=q^{\prime \prime} e^{\prime}$. Therefore, condition $\left(15^{\prime \prime}\right)$ reduces further to (22). $\|$

Consider, in particular, a uniformly proportionate variation of tariffs on the

26 Jones (1967) presents a synthesis of the two cases in a capital-mobile, Heckscher-Ohlin model.

${ }^{27}$ Provided, of course, that there is a non-empty set of domestic tax-subsidy schemes preferable to free trade, not to mention the autarkic state. 
assumption that situation $S^{\prime}$ is possessed of some tariffs $T^{\prime}$. In this case we have

$$
T^{\prime \prime}=\alpha T^{\prime} \quad(\alpha>0) .
$$

Condition (22) can therefore be rewritten as

$$
q^{\prime \prime} T^{\prime \prime} e^{\prime \prime} \geqq \alpha q^{\prime} T^{\prime} e^{\prime} .
$$

That is, the rate of increase (resp. decrease) in the net tariff revenue is not less (resp. greater) than the uniform rate of tariff increase (resp. decrease).

We can simplify conditions $\left(16^{\prime \prime}\right)$ and $\left(17^{\prime \prime}\right)$ in a similar fashion. If $T^{\prime \prime}=$ $C^{\prime \prime}=R^{\prime \prime}=0$, these conditions are all satisfied by equality. Hence, we are able to state

PROPOSITION 9: Free trade is preferable to any manner of restricted trade for a price-taking country.

In practice, the government often pursues policies to achieve specific objectives of its own. ${ }^{28}$ For instance, it may wish to raise a fixed amount of revenue by means other than lump-sum taxes. ${ }^{29}$ The commodity tax structure which minimizes the harm to consumers in such a case is investigated by Dixit (1970). One of his results can be extended to the present model with considerable gains in generality as well as in interpretation.

Proposition 10: Given a fixed amount of government's revenue, trade with appropriate uniform-rate taxes on consumption is preferable, for a price-taking country, to a situation with tariffs and/or other domestic taxes and subsidies.

Proof: Let $S^{\prime \prime}$ be the trading situation with uniform-rate taxes on consumption, and $S^{\prime}$ any other situation. Since a fixed amount of government's revenue is raised in both $S^{\prime}$ and $S^{\prime \prime}$, we have $b^{\prime}=b^{\prime \prime}=q^{\prime \prime} e^{\prime \prime}=q^{\prime} e^{\prime}$. For a price-taking country, we observe

$$
\begin{aligned}
p^{\prime \prime} C^{\prime \prime}\left(x^{\prime \prime}-x^{\prime}\right) & =p^{\prime \prime} C^{\prime \prime}\left(e^{\prime \prime}+y^{\prime \prime}+a^{\prime \prime}-e^{\prime}-y^{\prime}-a^{\prime}\right) \\
& =c^{\prime \prime} q^{\prime \prime}\left(e^{\prime \prime}-e^{\prime}\right)+c^{\prime \prime} p^{\prime \prime}\left(y^{\prime \prime}-y^{\prime}\right) \\
& =c^{\prime \prime} p_{r}^{\prime \prime}\left(y^{\prime \prime}-y^{\prime}\right)
\end{aligned}
$$

where $c^{\prime \prime}$ is the common rate of taxes on consumption such that $c^{\prime \prime} p^{\prime \prime} x^{\prime \prime}=-b^{\prime \prime}$. Hence, from conditions (4) and (16"), follows the assertion. ||

This result shows that if the government is to raise a fixed amount of revenue, a uniform-rate consumption tax scheme is the appropriate policy optimal among all possible mixes of tariffs and domestic taxes and subsidies. Aside from its allowance for intermediate and non-tradeable commodities, Proposition 10 is, therefore, more comprehensive than the statement that a uniform consumption

${ }^{28}$ Bhagwati (1971) gives a detailed taxonomic account of some of such policies.

${ }^{29}$ Perhaps for the purpose of reparation payment or economic aid to the rest of the world. 
tax structure is better than differentiated consumption tax structure as a means to provide the government with a given sum of purchasing power. ${ }^{30}$

On occasions the government may also wish to restrict the value of certain imports or exports, the value of certain consumptions, and the value of certain outputs or inputs at some fixed levels other than those of free trade. The policy problems which arise under such circumstances are discussed by Johnson (1964) and later elaborated by Ray (1971). Our method enables us again to give a thoroughgoing treatment of these issues.

Proposition 11: Given a fixed value of certain imports (resp. exports), trade with appropriate uniform-rate taxes or subsidies on those imports (resp. exports) is preferable, for a price-taking country, to a situation with other tariffs and/or domestic taxes and subsidies.

Proof: Consider trade with appropriate uniformate tariffs as $S^{\prime \prime}$, and any other situation as $S^{\prime}$. Let $t^{\prime \prime}$ be the common rate of tariffs applied to the group of imports or exports the value of which is to be restricted. Let $\hat{q}^{\prime \prime}$ be an $n$ vector obtained from $q^{\prime \prime}$ by merely replacing the prices of non-restricted commodities with zeros. By hypothesis, we then get

$$
q^{\prime \prime} T^{\prime \prime}\left(e^{\prime \prime}-e^{\prime}\right)=t^{\prime \prime}\left(\hat{q}^{\prime \prime} e^{\prime \prime}-\hat{q}^{\prime \prime} e^{\prime}\right)
$$

where $\hat{q}^{\prime \prime} e^{\prime \prime}$ and $\hat{q}^{\prime} e^{\prime}$ indicate the given value of imports or exports of the commodities under restriction. Since $\hat{q}^{\prime} e^{\prime}=\hat{q}^{\prime \prime} e^{\prime}$ for a price-taking country, condition (22) is satisfied by equality.

Likewise, we can establish

Proposition 12: Given a fixed value of consumption of certain tradeable commodities, trade with appropriate uniform-rate taxes or subsidies on the consumption of those commodities is preferable, for a price-taking country, to a situation with tariffs and/or other domestic taxes and subsidies.

Proposition 13: Given a fixed value of output (resp. input) of certain tradeable commodities, trade with appropriate uniform-rate taxes or subsidies on the output (resp. input) of those commodities is preferable, for a price-taking country, to a situation with tariffs and/or other domestic taxes and subsidies. ${ }^{31}$

30. Dixit considers this problem in the context of a closed economy on the assumption that all supply prices are constant and that there is a positive net transfer of purchasing power to consumers from somewhere like manna from the heaven. For a closed economy in which we have no terms of trade effect to worry about, Dixit's restrictive assumption is in fact unessential to the desired result.

31 Note that these two propositions are concerned only with the case where the constrained variable is the value of consumption or production of tradeable commodities. The result does not extend to the case with restricted value of consumption or production of non-tradeable commodities. 
Finally, it is most conceivable that tariffs and other forms of restrictive measures are invoked by the government to fix the volume of certain imports or exports, the volume of certain consumptions, and the volume of certain outputs or inputs at some assigned levels other than those of free trade. Working with a two-commodity model, Johnson (1964) illustrates the principle that tariffs are superior to domestic taxes and subsidies for the purpose of restricting the volume of imports. Similarly, Corden (1957) shows that a production subsidy is less costly than a tariff in achieving a given level of the importcompeting production. Bhagwati and Srinivasan (1969) study the case in which the use of a factor in production is restricted as well as the case in which the consumption of a commodity is the constrained variable. It is an easy matter to generalize these diverse results and place them in the common analytical perspective of this paper. ${ }^{32}$

Proposition 14: Given a fixed volume of certain imports (resp. exports), trade with appropriate tariffs on those imports (resp. exports) is preferable, for a pricetaking country, to a situation with other tariffs and/ordomestic taxes and subsidies.

Proof: Let the trading situation with appropriate tariffs be represented by $S^{\prime \prime}$, and any other situation by $S^{\prime}$. Since the volume of restricted imports or exports is given and invariable for both $S^{\prime}$ and $S^{\prime \prime}$, we have $e_{i}^{\prime}=e_{i}^{\prime \prime}$ for $t_{i}^{\prime \prime} \neq 0$, implying that condition (22) is satisfied by equality. ||

Similarly, we can prove

Proposition 15: Given a fixed volume of certain consumptions, trade with appropriate taxes or subsidies on those consumptions is preferable, for a pricetaking country, to a situation with tariffs and/or other domestic taxes and subsidies.

Proposition 16: Given a fixed volume of certain outputs (resp. inputs), trade with appropriate taxes or subsidies on those outputs (resp. inputs) is preferable, for a price-taking country, to a situation with tariffs and/or other domestic taxes and subsidies.

Propositions 11-16 confirm the point recognized by Bhagwati (1971) that when distortions have to be introduced into the economy in order to constrain the value of certain variables, the optimal (or least-cost) method of doing this is to choose that policy-intervention which creates the distortion affecting directly the constrained variable. In a controversial article, Lipsey and Lancaster (1956-1957) claim that there is no a priori way to judge between sub-optimal situations. Their claim is valid only if little is known a priori. In fact, our

${ }^{32}$ Tan (1971) also extends these results to three special models which allow for inter-industry linkages, the use of intermediate goods, and non-tradeable commodities. Our method provides an alternative and more general treatment of the problem. 
results suggest that policy makers should be able to survive by the help of their wisdom and expert knowledge..$^{33}$

\section{ECONOMIC GROWTH AND UNILATERAL TRANSFER}

We have so far confined our attention to the economy with immutable technology and constant endowment. From the standpoint of this study, however, there is no special reason for us to adhere to this convention. After all, technology, as well as endowment, is just one of the structural determinants of the economy such as the foreign environment, the government taxes and subsidies, etc. Technological progress, along with endowment expansion, serves as a major factor in economic growth which is supposed to increase economic welfare under ordinary circumstances. ${ }^{34}$ Nonetheless, they can be actually harmful to a country engaged in external trade. It is because of this ambiguity that we wish to discuss economic growth and also touch upon the comparable transfer problem.

Let us consider here trading situations with only tariffs since our method will apply readily to other cases. Suppose that an economic growth has changed situation $S^{\prime}$ into situation $S^{\prime \prime}$. The difference between the two is assumed to consist only of some technological progress and endowment expansion giving rise to the economic growth. Thus, we have to leave the hypothesis of Theorem 2 and instead postulate

$$
a^{\prime \prime} \geq a^{\prime} \quad\left(a^{\prime \prime} \neq a^{\prime}\right) ; \quad Y^{\prime \prime} \supset Y^{\prime} \quad\left(Y^{\prime \prime} \neq Y^{\prime}\right) .
$$

From Theorem 1, we obtain

Proposition 17: If condition

$$
\left(q^{\prime}-q^{\prime \prime}\right) e^{\prime}+q^{\prime \prime} T^{\prime \prime}\left(e^{\prime \prime}-e^{\prime}\right)+p^{\prime \prime}\left\{\left(y^{\prime \prime}-y^{\prime}\right)+\left(a^{\prime \prime}-a^{\prime}\right)\right\} \geqq 0
$$

is satisfied, the economic growth is beneficial.

Proof: By assumption, we have $C^{\prime \prime}=R^{\prime \prime}=0$, and therefore, $p_{r}^{\prime \prime}=p^{\prime \prime}$. Also, $b^{\prime}=b^{\prime \prime}$ implies $q^{\prime \prime}\left(e^{\prime \prime}-e^{\prime}\right)=\left(q^{\prime}-q^{\prime \prime}\right) e^{\prime}$. With these relationships, condition (13) simplifies to (23). I|

Note that the third term on the left-hand side of condition (23) contains the gain from the growth and is assumed to be positive. We cannot, however,

${ }^{33}$ Likewise, Bhagwati and Ramaswami (1963) asserts that a tariff is not necessarily superior to free trade in the presence of domestic distortions. But this assertion is also misleading. Using the same model, Ohyama (1972), along with Kemp and Negishi (1969), demonstrates the existence of a tariff superior to free trade.

${ }^{34}$ In this statement we consider endowment expansion as the phenomena such as the natural growth of cattle and timber woods. Naturally, we must except population growth which affects the set of consumers. 
be so sure of the sign of the first and second terms. Bhagwati (1958), for instance, argues that economic growth may lead to a sufficiently accute terms of trade deterioration imposing a loss of real income to override the primary gain from the growth itself. He aptly names this phenomenon "immiserizing growth". ${ }^{35}$ Appropriately reinterpreting Theorem 1, we readily get

\section{Proposition 18: If condition}

$$
\left(q^{\prime \prime}-q^{\prime}\right) e^{\prime \prime}+q^{\prime} T^{\prime}\left(e^{\prime}-e^{\prime \prime}\right)-p^{\prime}\left\{\left(y^{\prime \prime}-y^{\prime}\right)+\left(a^{\prime \prime}-a^{\prime}\right)\right\} \geqq 0
$$

is satisfied, the economic growth is harmful.

Now, the term $\left(q^{\prime \prime}-q^{\prime}\right) e^{\prime \prime}$, if positive, measures the terms of trade deterioration in the Paache sense due to the economic growth. On the other hand, the term $p^{\prime}\left\{\left(y^{\prime \prime}-y^{\prime}\right)+\left(a^{\prime \prime}-a^{\prime}\right)\right\}$ measures the gain in profits and endowment income in the Laspeyres sense. In the absence of tariffs, immiserizing growth will occur if

$$
\left(q^{\prime \prime}-q^{\prime}\right) e^{\prime \prime} \geqq p^{\prime}\left\{\left(y^{\prime \prime}-y^{\prime}\right)+\left(a^{\prime \prime}-a^{\prime}\right)\right\}
$$

that is, if the unfavorable terms of trade effect outweighs the growth effect. Thus, an export-biased expansion may not be felicitous when the world is not ready to absorb the additional output only with a moderate fall in price.

Consider now a small growth in a price-taking country which does not affect the world price of tradeable commodities. Under free trade there can be no dimunition of the growth gain. If there are tariffs, however, even a country without any monopoly power in world trade is not completely exempt from immiserizing growth. Since we assume $T^{\prime}=T^{\prime \prime}$, sufficient condition for that eventuality is written as

$$
q^{\prime} T^{\prime} e^{\prime}-q^{\prime \prime} T^{\prime \prime} e^{\prime \prime} \geqq p^{\prime}\left\{\left(y^{\prime \prime}-y^{\prime}\right)+\left(a^{\prime \prime}-a^{\prime}\right)\right\} .
$$

The left hand-side of this condition, if positive, represents a reduction in the net tariff revenue brought about by the economic growth. Johnson (1967) shows that a technological progress in the domestic production of protected import-competing industry can actually hurt the country's economic welfare through a decrease in the tariff revenue..$^{36}$

Receiving a unilateral transfer in kind from abroad resembles, at first sight, an autonomous expansion of the country's endowment. In fact, the condition for a beneficial transfer will take the same form as condition (23). This

${ }^{35}$ Earlier economists were as well aware of this possibility. For instance, Edgeworth (1894, p. 40) discussed the possible adverse consequence of a technological progress in the export industries attributing the paradox to John S. Mill.

${ }^{36}$ Bhagwati (1968 b) extends this possibility to the case of domestic distortions such as external economies and diseconomies and inter-industry factor reward differentials which we assume away in this paper. The underlying logic is, however, the same as in the case of tariffs. 
resemblance is, of course, rather superficial, and fades away as soon as one realizes that a transfer receipt in kind gives rise simultaneously to the contraction of endowment in the rest of the world. Its welfare effect will differ depending on the nature of the commodities that are transferred. ${ }^{37} \quad$ In case of a transfer in purchasing power, it is established in the context of a simpler model of trade that if certain fundamental assumptions are satisfied, "immiserizing" transfer receipt will never take place under free trade..$^{38}$ This, however, does not seem to be the case in the presence of tariffs.

Suppose that $S^{\prime}$ now corresponds to a situation with no foreign transfer and $S^{\prime \prime}$ to the same situation except for a transfer receipt $b^{\prime \prime}$. We may reinterpret Theorem 1 to obtain

Proposition 19: If condition

$$
\left(q^{\prime \prime}-q^{\prime}\right) e^{\prime \prime}+q^{\prime} T^{\prime}\left(e^{\prime}-e^{\prime \prime}\right)+p^{\prime}\left(y^{\prime}-y^{\prime \prime}\right) \geqq b^{\prime \prime}
$$

is satisfied, the transfer receipt is harmful.

If world prices happen to be unchanged in the face of the transfer, condition (25) becomes

$$
q^{\prime} T^{\prime} e^{\prime}-q^{\prime \prime} T^{\prime \prime} e^{\prime \prime} \geqq b^{\prime \prime}
$$

meaning that the reduction in the tariff revenue be at least as large in value as the transfer receipt itself. ${ }^{39}$ This condition may be fulfilled if some tarifffree tradeables are inferior in social consumption. From a practical point of view, however, it is more interesting to observe that a transfer receipt produces an additional welfare effect in the form of chainging tariff revenue on top of the obvious direct effect and the much discussed terms of trade effect. This point is hardly recognized in the literature on the transfer problem. ${ }^{40}$

We have so far assumed that tariffs are unchanged in the face of economic growth or unilateral transfer. But suppose that the sole objective of tariffs is to restrict the volume of imports or exports at some assigned level. Then, tariffs are to be modified so as to achieve this objective as economic growth or transfer receipt tends to affect the country's external trade. So far as this modification of tariffs is appropriately carried out, economic growth, as well as transfer receipt, is bound to be beneficial for a price-taking country. To see this point, note that the first two terms of condition (23) vanish to zero

${ }^{37}$ One must distinguish the transfer of tradeable commodities from that of non-tradeable commodities.

${ }^{38}$ See for example Mundell (1960), pp. 79-80.

${ }^{39}$ In this special case, the term $p^{\prime}\left(y^{\prime}-y^{\prime \prime}\right)$, as well as $\left(q^{\prime \prime}-q^{\prime}\right) e^{\prime \prime}$, vanishes to zero. In fact, $p^{\prime} y^{\prime} \geqq p^{\prime} y^{\prime \prime}$, but $p^{\prime} y^{\prime}=p^{\prime \prime} y^{\prime} \leqq p^{\prime \prime} y^{\prime \prime}=p^{\prime} y^{\prime \prime}$.

${ }^{40}$ See Samuelson $(1952,1954)$, which investigate the terms of trade effect of a transfer payment. Ohyama (1970) provides a supplementing analysis pointing out the tertiary effect through a change in the volume and composition of trade under tariffs. 
under such a circumstance. The same conclusion will also hold for a pricetaking country with domestic taxes and subsidies designed to restrict the volume of certain consumptions, outputs, and inputs at some given level.

\section{THE INFANT INDUSTRY ARGUMENT}

We have already established that free trade is preferable to any other situation for a price-taing country. Underlying this free-trade proposition, however, is the assumption that the productive capacity of the country is unaffected by the volume and composition of its foreign trade. This assumption is at best questionable at times: it has indeed invited persistent challenges since the days of Hamilton and List. These challenges have culminated in a legitimate case for protection. The infant industry argument, as it is so-called, maintains that, in some industries, producers (or the firms) learn from the experience thereby adding to efficiency and expanding the basis of national productive capacity through time. If free trade is expected to damage or extirpate such industries in their "infantile" stage through foreign competition, gains from trade must be weighed against the future benefit of the learning processes to be forgone. The free-trade proposition is no longer tenable without qualifications.

Following Kemp (1960), let us digress to classify the relevant learning processes into two familiar categories. A learning process is internal to the firm if it helps to remunerate only the firm which actually carries on production. In this case, we shall speak of dynamic internal economies. Correspondingly, a process is external to the firm if the experience is non-appropriable, and necessarily benefits other firms inside (and perhaps also outside) the industry. We shall then speak of dynamic external economies. Kemp asserts that, under certainty and perfect markets, the existence of dynamic internal economies can never be the pretext for protection. But as Negishi (1968) and Ray (1970) point out, ${ }^{41}$ Kemp's conclusion hinges crucially on his interpretation of Bastable's test for the legitimacy of infant industry protection. According to his interpretation, Bastable's test requires that the future gain accruing to the matured industry be sufficient to compensate present cost falling on the infant industry during the learning period. Kemp thus views Bastable's test only in terms of the producers' profitability in the long-run. No wonder that the profit incentive is enough to carry out the venture which passes such a test. It is, however, not the producers' profitability, but the consumers' welfare that counts in deciding upon the propriety of protection. We wish to reconsider the infant industry argument as yet another application of our

${ }^{41}$ Negishi considers the infant industry argument from the viewpoint of the world. We shall return to this problem later in Section XI to discuss the world gains from trade. 
methodology supporting, in particular, the position taken by Negishi and Ray.

For simplicity, let us consider a two-period model of the economy. A commodity in the first (present) period and the same commodity in the second (future) period are, then, different economic objects. We have to reinterpret our vectors so that they now represent the quantities of the two periods:

$$
\begin{aligned}
& x=\left({ }^{1} x,{ }^{2} x\right) \\
& y=\left({ }^{1} y,{ }^{2} y\right) \\
& p=\left({ }^{1} p,{ }^{2} p\right) \text { etc. }
\end{aligned}
$$

where the left-hand superscripts indicate the period of the vectors. In a twoperiod equilibrium, the rate of interest is implicitly determined by the price vector, $p=\left({ }^{1} p,{ }^{2} p\right)$. Assume that there exists a certain (positive) level of the infant industry output below which it cannot generate internal or external dynamic economies, and that the level is not achieved without protection in the first period. Since learning is a time-consuming process, dynamic economies are assumed to materialize only in the second period given the appropriate protection in the first. To sharpen the argumentative edge, let us further assume that there are no dynamic economies in the non-infant industries. As we have shown above, the desirable level of the infant industry outputs is best achieved by appropriate subsidies on those outputs.

Now suppose that situation $S^{\prime}$ stands for free trade without any protection, and $S^{\prime \prime}$ for the state with protection in the form of production subsides in the first period.

Proposition 20: If condition

$$
p_{r}^{\prime \prime}\left(y^{\prime \prime}-y^{\prime}\right)+p^{\prime \prime}\left(a^{\prime \prime}-a^{\prime}\right) \geqq p^{\prime \prime} R^{\prime \prime}\left(y^{\prime \prime}-y^{\prime}\right)
$$

is satisfied, the infant industry protection by means of propoduction subsidies is beneficial for a price-taking country.

Proof: Let $T^{\prime \prime}=C^{\prime \prime}=0$ and $q^{\prime \prime}\left(e^{\prime \prime}-e^{\prime}\right)=0$. Then, condition (13) in Theorem 1 reduces to (27). 11

According to Kemp's criterion, the protection is not to be recommended if there are only internal dynamic economies, for the desired level of infant industry outputs are assumed to be unprofitable. To discuss this point, let $w$ and $z$ be $n$-vectors of aggregate production of infant and non-infant industries. Thus

$$
y=w+z
$$

and we can rewrite condition (26) as

$$
p_{r}^{\prime \prime}\left(z^{\prime \prime}-z^{\prime}\right)+p^{\prime \prime}\left(a^{\prime \prime}-a^{\prime}\right) \geqq p^{\prime \prime}\left(w^{\prime}-w^{\prime \prime}\right)
$$

on the assumption that there are no taxes or subsidies on the production of 
non-infant industries. In particular, if $w^{\prime}=0$, the right-hand side of this condition is positive since production $w^{\prime \prime}$ is unprofitable without protective subsidies, or $p^{\prime \prime} w^{\prime \prime}<0$. On the other hand, the left-hand side may as well be positive in the presence of non-tradeable commodities because of the profit maximization condition for non-infant industries and the possible augmentation (in efficiency units) of factors of production specific to the firms of infant industries. Despite the unprofitability assumption, condition (26) may be satisfied, and therefore protection justified even though the available learning processes are all internal to the firms. ${ }^{42}$. At any rate, condition (26) may or may not hold irrespective the nature of dynamic economies occuring in the infant industries. ${ }^{43}$

On the other hand, if there are neither dynamic external economies nor non-tradeable commodities, we obtain

$$
p^{\prime}\left(z^{\prime}-z^{\prime \prime}\right)+p^{\prime}\left(a^{\prime}-a^{\prime \prime}\right)=0>p^{\prime} w^{\prime \prime}
$$

since, in this case, we must have $p^{\prime}=p^{\prime \prime}$ and $a^{\prime}=a^{\prime \prime}$. It implies that the protection of unprofitable infant industries is harmful for a price-taking country. ${ }^{44}$ Kemp's argument is therefore valid in the special case in which all commodities are tradeable.

Finally, protection may take the form of import taxes in spite of the fact that they are more costly than production subsidies. To consider this case, let $S^{\prime \prime}$ now represent the state with protective tariffs. Proposition 20 is no longer relevant. From Theorem 1, we instead get

Proposition 21: If condition

$$
p^{\prime \prime}\left\{\left(y^{\prime \prime}-y^{\prime}\right)+\left(a^{\prime \prime}-a^{\prime}\right)\right\} \geqq q^{\prime \prime} T^{\prime \prime}\left(e^{\prime}-e^{\prime \prime}\right)
$$

is satisfied, the infant industry protection by means of tariffs is beneficial for a. price-taking country.

\section{THE CUSTOMS UNIONS ISSUE}

Up to this point we have made no attempt to go beyond the viewpoint of a single country trading with the rest of the world. This is of course due to

${ }^{42}$ At this point, it should be recalled that, under the convexity of social preference relation, condition (26) is merely sufficient (and not necessary) for the justification of infant industry protection.

${ }^{43}$ Haberler (1950) provided a diagramatic demonstration of the essential argument, which was somehow neglected in later controversies.

${ }^{44}$ If $w^{\prime}=0$, we have

$$
\begin{aligned}
p^{\prime}\left(x^{\prime}-x^{\prime \prime}\right) & =p^{\prime}\left(y^{\prime}-y^{\prime \prime}\right)+p^{\prime}\left(a^{\prime}-a^{\prime \prime}\right) \\
& =p^{\prime}\left(z^{\prime}-z^{\prime \prime}-w^{\prime \prime}\right)+p^{\prime}\left(a^{\prime}-a^{\prime \prime}\right)
\end{aligned}
$$


the nature of our model described at the outset. A little reflection, however, will reveal that we can at times reinterpret the single country's viewpoint so as to deal with the problem of many countries. Our method remains indeed applicable whenever a group of several countries acts like a single country providing a common set of prices to measure and compare the sum of national consumption bundles of two situations. The customs unions issue provides a shining example of such a circumstance, and certainly deserves a separate treatment on its own right. Let us assume that (i) the customs unions abolish all tariffs among the member countries; (ii) it sets up common external tariffs; and (iii) it fully coordinates distributional policies inside the union. Introducing picturesque concepts of trade creation and trade diversion, Viner (1950) aptly illustrates the generally ambiguous nature of the effect of the customs union. In fact, like many other statements on trade and welfare, it is only conditional that the customs union will augment the welfare of any concerned party.

Suppose that there are $v$ countries in the world, and that $s(<v)$ countries formed a customs union. We indicate the countries by putting left-hand subscripts to all symbols. Let $S^{\prime}$ and $S^{\prime \prime}$ represent the pre- and post-union situations wherein domestic taxes and subsidies are assumed to be non-existent.

Proposition 22: If condition

$$
\left(q^{\prime}-q^{\prime \prime}\right) \sum_{h=1}^{s}{ }_{h} e^{\prime}+q^{\prime \prime} T^{\prime \prime}\left(\sum_{h=1}^{s}{ }_{h} e^{\prime \prime}-\sum_{h=1}^{s}{ }_{h} e^{\prime}\right) \geqq 0
$$

is satisfied, the post-union situation is preferable to the pre-union situation for the customs union as a whole.

Proof. We may consider the members of the customs union as if they were a single country because of the distributional coordination available in the post-union situation. Condition $\left(15^{\prime}\right)$ is then applicable with $b^{\prime \prime}=\sum_{h=1}^{s} b^{\prime}$, and may be rewritten as (28).

The first term on the left-hand side of condition (28) indicates the terms of trade effect, and the second term, the trade expansion (contraction) effect on the welfare of the customs union. If the terms of trade effect is negligible, and free trade prevails in the rest of the world, we can discuss the gain from the formation of the union solely in terms of the trade expansion (contraction) effect along the line made popular by Meade (1955a). For example, the expansion of the tariff-protected net imports will be, ceteris paribus, sufficient to suggest an increase of the world real income as well as the union's welfare. Note, however, that the much discussed trade creating effect does not appear explicitly in condition (28). In fact it is buried in the omitted expression:

$$
p^{\prime \prime}\left(\sum_{h=1}^{s}{ }_{h} y^{\prime \prime}-\sum_{h=1}^{s}{ }_{h} y^{\prime}\right) \geqq 0
$$


and yet it certainly affects the condition indirectly through its expansive effect on external trade. In general, condition (28), together with condition (15"), provides a complete set of references for testing the welfare effect on the union itself as well as on each country in the outside world.

Criticizing Viner's pioneering analysis, Meade (1955a), Gehrels (1956-57), and Lipsey $(1957,1960)$ demonstrate that the purely trade diverting union may just easily be beneficial in the presence of a convex social preference relation. To exclude trade creation and the terms of trade effect, they focus upon a customs unions of exchange economies with no monopoly power in world trade. Suppose as a limiting case that there is no trade diversion, either. Then, condition (28) is satisfied by equality, and the members' welfare is shown to increase after the union (recall Lemma 3). By continuity, we may conclude that the union remains beneficial even with some trade diversions. In fact, their simple example relates to the case which fails to meet condition (28), and serves to remind us once again of the sufficiency nature of our welfare criterion under the convexity of consumers' preference relations.

More recently, Kemp (1964) and Vanek (1965) advocate an interesting scheme of the tariff-compensating customs union. We may define it as the union which sets its common external tariffs so as to preserve the same volume and composition of net trade with the rest of the world as occured before it was formed.

Proposition 23: A tariff-compensating customs union is bound to benefit itself.

Proof: Refering back to Proposition 22, we find

$$
\sum_{h=1}^{s}{ }_{h} e^{\prime}=\sum_{h=1}^{s}{ }_{h} e^{\prime \prime}
$$

for a tariff compensating customs union. Hence,

$$
\left(q^{\prime}-q^{\prime \prime}\right) \sum_{h=1}^{s}{ }_{h} e^{\prime}=q^{\prime} \sum_{h=1}^{s}{ }_{h} e^{\prime}-q^{\prime \prime} \sum_{h=1}^{s} e_{h} e^{\prime \prime}=0 .
$$

Thus, both the first and the second terms in condition (28) vanish to zero. ||

Clearly, a tariff-compensating union does not hurt the rest of the world. Therefore, it is also beneffcial for the world as a whole. ${ }^{45}$ As Vanek suggests, it may be useful to think of a customs union as adopting the compensating tariffs in the ffrst step, and then shifting to the final tariffs in the second. This amounts to a conceptual device of splitting up the welfare effect of the union conveniently into two parts to examine them separately. The first step is necessarily beneficial. The second step is analytically equivalent to a single

\footnotetext{
${ }^{45}$ In fact, the idea of a tariff-compensating customs union can be seen as a natural development of the Meade-Gehrels-Lipsey proposition.
} 
country's act of tariff reform..$^{46}$

\section{THE WORLD GAINS FROM TRADE}

There seems to be little literature along the line of the present study which adequately deals with the world gains from trade. Since we have already set out to consider the situations explicitly involving several countries, we shall follow the logic to its end, and fill the void to some extent. The familiar free trade doctrine immediately follows from condition (28). Suppose that $s=v$. In other words, imagine that all the countries get together and form the world customs union. That is free trade. We may now rewrite (28) simply as

$$
\left(q^{\prime}-q^{\prime \prime}\right) \sum_{h=1}^{v}{ }_{h} e^{\prime}=-q^{\prime \prime} \sum_{h=1}^{v}{ }_{h} e^{\prime} \geqq 0 \text {. }
$$

But this condition necessarily holds since $q^{\prime \prime} \geqq 0$ and $\sum_{h=1}^{v} e^{\prime} \leqq 0$. If the set of free commodities is identical for the two situations, the condition is to be satisfied by equality. Thus, free trade is preferable to any other situation for the world as a whole provided that there is a proper redistributional arrangement among nations.

In view of Proposition 1, we may also note that trade restricted by tariffs is preferable to no trade for all countries, i.e., for the world. Clearly, we cannot obtain the same unconditional statement for trade restricted by domestic taxes and subsidies. ${ }^{47}$ To proceed further, let us assume the presence of a world government coordinating all the functions of national governments. First, we can apply Theorem 2-(ii) to obtain

Proposition 24: Let $T^{\prime \prime}=R^{\prime \prime}=0$. Then, if condition

$$
q^{\prime \prime} C^{\prime \prime} \sum_{h=1}^{v}\left({ }_{h} x^{\prime \prime}-{ }_{h} x^{\prime}\right) \geqq 0
$$

is satisfied, situation $S^{\prime \prime}$ is preferable to situation $S^{\prime}$.

Proof: Note that $C^{\prime \prime}$ represents the common taxes and subsides applied throughout the world in situation $S^{\prime \prime}$. Consequently, all consumers are supposed to face the same price, which makes Theorem 2-(ii) applicable to the world. It then suffices to rewrite condition (16) and note $\left(q^{\prime}-q^{\prime \prime}\right) \sum_{h=1}^{v} e^{\prime} \geqq$ $0 . \mid 1$

${ }^{46}$ A single country's tariff reform, say a reduction of tariffs, however, will not be unambiguous in its effect on the welfare of the tariff-ridden world. See Meade (1955 b, pp. 511520) and also Ozga (1955).

${ }^{47}$ Similarly, trade may not be conducive to the world real income if non-self-financing tariffs are prevalent. This point generalizes Jones' observation (1961, pp. 173-174) about a Grahamesque, multi-country, multi-commodity model. 
Similarly, from Theorem 2-(iii) we can derive

Proposition 25: Let $T^{\prime \prime}=C^{\prime \prime}=0$. Then, if condition

$$
q^{\prime \prime} \sum_{h=1}^{v}{ }_{h} R^{\prime \prime}\left({ }_{h} y^{\prime}-{ }_{h} y^{\prime \prime}\right) \geqq 0
$$

is satisfied, situation $S^{\prime \prime}$ is preferable to situation $S^{\prime}$.

In case there are only taxes and subsidies on production in situation $S^{\prime \prime}$, they can be different from country to country because of the fact that consumers' price is identical throughout the world. In view of conditions (29) and (30), we find that there is a striking correspeondence between the world envisioned here and a price-taking country with no external tariffs. In each case, we are able to disregard the cumbersome term $\left(q^{\prime}-q^{\prime \prime}\right) e^{\prime}$ reflecting the terms of trade effect. Thus, a number of welfare propositions which are valid for a price-taking country are also applicable to the world.

First of all, proposition 9 corresponds to the free trade doctrine which we have just established. Similarly, propositions 10, 15, 16 and 20 can be readily reformulated to fit in with the present context. For example, we can state

Proposition 26: Given a fixed volume of certain outputs (resp. inputs) in certain countries, trade with appropriate taxes or subsidies on those outputs (resp. inputs) is preferable, for the world as a whole, to a situation with tariffs and/or other taxes and subsidies.

In correspondence to proposition 16, this result tells us that, from the viewpoint of the world, a national scheme of production taxes and subsidies is the optimal way of achieving a target level of any output or input in any country. We may then proceed to consider the infant industry protection by means of national production subsidies just as we considered it for a price-taking country.

Proposition 27: If condition

$$
\sum_{h=1}^{v}{ }_{h} p_{r}^{\prime \prime}\left({ }_{h} y^{\prime \prime}-{ }_{h} y^{\prime}\right)+q^{\prime \prime}\left(\sum_{h=1}^{v}{ }_{h} a^{\prime \prime}-\sum_{h=1}^{v}{ }_{h} a^{\prime}\right) \geqq q^{\prime \prime} \sum_{h=1}^{v}{ }_{h} R^{\prime \prime}\left({ }_{h} y^{\prime \prime}-{ }_{h} y^{\prime}\right)
$$

is satisfied, the infant industry protection by means of national production subsidies is beneficial for the world as a whole.

Generally speaking, if tariffs are non-existent, and if taxes and subsidies on consumption are common to all countries, we find a correspondence in the above sense between the world and a price-taking country. ${ }^{48}$ We may refer to this fact as a "correspondence principle" in trade and welfare. It is speci-

\footnotetext{
${ }^{48}$ Strictly speaking, this correspondence fails to apply to the propositions on a price-taking country which depend not only on the absence of the terms of trade effect but also on the constancy of the price of each tradeable commodity. Thus propositions 12 and 13 cannot be held valid for the world.
} 
fically pertinent to the familiar notion of the "ideal" world economy where free trade prevails among countries except some national schemes of production subsidies designed to foster infant industries under the auspices of a world govrnment. ${ }^{49}$

\section{CONCLUDING REMARKS}

We have derived numerous propositions from our basic theorem of welfare comparison thereby showing that most of the welfare propositions obtained in simple models of trade are viable in the presence of trade in intermediate goods and factor services as well as in the presence of any number of non-traded commodities. Some of our propositions may be considered to be worthwhile from a puristic viewpoint, while many of the conditional statements will only satisfy non-purists. But we wish to emphasize the simplicity and the methodological uniformity of our approach which compares two situations which may differ from each other in any manner and respect except in the set of consumers. If employed with enough caution, it may serve further useful purposes.

The lack of analysis of external economies and diseconomies may be pointed out as a major qualification of this study. When we consider the government as a producer or a consumer of public goods, this qualification may apper particularly restrictive: the external effect of public goods is often too obvious to escape one's eyes. ${ }^{50}$ As is well-known, externalities among economic agents will give rise to interdependence among their behaviors and invalidate the equilibrium conditions for producers and consumers. To remedy such a situation, it would be necessary to set up a system of artificial markets for externalities so that both external economies and diseconomies are properly counted as commodities. ${ }^{51}$ Note, however, that external diseconomies are comparable to the supply of labor, and their absence to the endowment of leisure. ${ }^{52}$ In fact, external diseconomies are not themselves commodities, but

${ }^{49}$ An adept blueprint of such a world economy is found in Tinbergen (1962).

${ }^{50}$ As in the case of public goods which are not subject to the exclusion principle, the consumption, or production of some commodities by an economic agent may affect a number of other economic agents at the same time. In such an event, it would be necessary to establish an agreement among those affected on the individual shares in the price of the externalities. For closely related concepts, see Musgrave (1959).

${ }^{51}$ But for the governmental intervention in the economy as a law-enforced broker between potential sellers and buyers, the scheme would be largely impractical because of the thinness of many markets for externalities. In fact, it would be economically equivalent to an alternative remedy by means of domestic taxes and subsidies if both are administered properly.

${ }^{52}$ For example, consider a fisherman who suffers from a water-polluting factory only in business aspects. He is not in the position to supply his diseconomies beyond the degree of water pollution at which he goes out of business. Otherwise, he would supply an infinite amount of diseconomies at any positive price. 
rather losses of the commodities which, in their full endowment, represent perfect freedom from external diseconomies. No one is, therefore, able to supply his external diseconomies beyond the tolerable degree of their irksomeness. This point is indeed essential to the workability of artificial markets for externalities. But as long as externalites are assumed to be internalized through such a scheme, the present model remains applicable without any formal modification.

\section{ACKNOWLEDGMENTS}

This paper was taken from my Ph. D. thesis submitted to the University of Rochester in February 1972. I would like to thank Professors Lionel W. Mckenzie, Ronald W. Jones and Akira Takayama for their guidance and many helpful comments which led to improvements of my initial thoughts. I am also indebted to Professors Murray C. Kemp, Henry Y. Wan, Leon L. Wegge, Masao Fukuoka, Kiyoshi Ikemoto, Yoko Sazanami, and my friends, Messrs. Alok Ray and Kunio Kawamata for their kind criticisms. Finally, I would like to acknowledge my appreciation to Professors Noboru Yamamoto, Ichiro Ohkuma and Katsu Yanaihara of Keio University for their continued encouragement.

Keio University

\section{REFERENCES}

[1] Baldwin, R. E., 1952, "The New Welfare Economics and Gains in International Trade" Quarterly Journal of Economics, Vol. 66 (February), 90-101.

[2 ] Bhagwati, J., 1958, "Immiserizing Growth: A Geometrical Note," Review of Economic Studies, Vol. 25 (June), 201-205.

[3] Bhagwati, J., 1964, "The Pure Theory of International Trade: a Survey," Economic Journal, Vol. 74 (March), 1-81.

[4] Bhagwati, J., 1968 a, "The Gains from Trade Once Again." Oxford Economic Papers, Vol. 20 (July), 137-148.

[ 5 ] Bhagwati, J., 1968 b, "Distortions and Immiserizing Growth: a Generalization," Review of Economic Studies, Vol. 35 (October), 481-485.

[6] Bhagwati, J., 1971, "The Generalized Theory of Distortions and Welfare," in J. Bhagwati et al., Trade, Balance of Payments and Growth, Papers in International Economics in Honor of Charles P. Kindleberger, Amsterdam: North-Holland.

[ 7 ] Bhagwati, J. and V. K. Ramaswami, 1963, "Domestic Distortions, Tariffs, and the Theory of Optimum Subsidy," Journal of Political Economy, Vol. 71 (February), 44-50.

[ 8 ] Bhagwati, J. N. and T. N. Srinivasan, 1969, "Optimal Intervention to Achieve Noneconomic Objectives," Review of Economic Studies, Vol. 36 (January), 27-38.

[9] Chipman, J. S., 1965, "A Survey of International Trade: Part 2, the Neo-classical Theory," Econometrica, Vol. 33 (October), 685-760.

[10] Corden, W. M., 1957, "Tariffs, Subsidies, and the Terms of Trade," Economitrica, Vol. 24 (August), 235-242.

[11] Debreu, G., 1959, Theory of Value, New York: John Wiley and Sons.

[12] Diamond, P. A., and J. A. Mirrlees, 1971, "Optimal Taxation and Public Production I: Production Efficiency" American Economic Review, Vol. 61 (March) 8-27. 
[13] Diamond, P. A., and J. A. Mirrlees, 1971, "Optimal Taxation and Public Production II: Tax Rules," American Economic Review, Vol. 61 (June), 261-278.

[14] Dixit, A. K., 1970, "On the Optimal Structure of Commodity Taxes," American Economic Review, Vol. 60 (1970), 107-116.

[15] Edgeworth, F. Y., 1894, "The Theory of International Values," Economic Journal, Vol. 4 (March), 35-50.

[16] Gehrels, F., 1956-1957, “Customs Unions from a Single Country Viewpoint," Review of Economic Studies, Vol. 24 (1), 61-64.

[17] Haberler, G., 1950, "Some Problems in the Pure Theory of International Trade," Economic Journal, Vol. 60 (June), 223-40.

[18] Inada, K., 1967, “A Note on the Heckscher-Ohlin Theorem," Economic Record, Vol. 43 (March), 88-96.

[19] Johnson, H. G., 1960, "The Cost of Protection and the Scientific Tariff," Journal of Political Economy, Vol. 68 (August), 327-345.

[20] Johnson, H. G., 1964, "Tariffs and Economic Development: Some Theoretical Issues," Journal of Development Studies, Vol. 1 (October), 3-30.

[21] Johnson, H. G., 1967, "The Possibility of Income Losses from Increased Efficiency or Factor Accumulation in the Presence of Tariffs," Economic Journal, Vol. 77 (March), 151-154.

[22] Jones, R. W., 1961, "Comparative Advantage and the Theory of Tariffs: a MultiCountry, Multi-Commodity Model." Review of Economic Studies, Vol. 28 (June), 161175.

[23] Jones, R. W., 1967, "International Capital Movements and the Theory of Tariffs and Trade," Quarterly Journal of Economics, Vol. 81 (February), 1-38.

[24] Jones, R. W., 1969, "Tariffs and Trade in General Equilibrium: Comment," American Economic Review, Vol. 59 (June), 418-424.

[25] Kemp, M. C., 1960, "The Mill-Bastable Infant Industry Dogma," Journal of Political Economy, Vol. 68 (February), 65-67.

[26] Kemp, M. C., 1962, "The Gains from International Trade," Economic Journal, Vol. 72 (December), 803-819.

[27] Kemp. M. C., 1964, The Pure Theory of International Trade, Englewood Cliffs, N.J.: Prentice-Hall.

[28] Kemp, M. C., 1968, "Some Issues in the Analysis of Trade Gains," Oxford Economic Papers, Vol. 20 (July), 194-161.

[29] Kemp, M. C., 1969, The Pure Theory of International Trade and Investment. Englewood Cliffs, N.J.: Prentice-Hall.

[30] Kemp, M. C. and T. Negishi, 1969, "Domestic Distortions, Tariffs, and the Theory of Optimum subsidy,' Journal of Political Economy, Vol. 77 (Nov./Dec.), 1014-1016.

[31] Kemp, M. C. and T. Negishi, 1970, "Variable Returns to Scale, Commodity Taxes, Factor Market Distortions and their Implications for Trade Gains," Swedish Journal of Economics, No. 1 (January), 1-11.

[32] Kennedy, C., 1954, "An Alternative Proof of a Theorem in Welfare Economics,' Oxford Economic Papers, Vol. 6 (February), 98-99.

[33] Kravis, I. B., 1956, "Availability and Other Influences on the Commodity Composition of Trade," Journal of Political Economy, Vol. 64 (April), 143-155.

[34] Krueger, A. O. and H. Sonnenschein, 1967, "The Terms of Trade, the Gains from Trade, and Price Divergence," International Economic Review, Vol. 8 (February), 121-127.

[35] Leontief, W. W., 1933, "The Use of Indifference Curves in the Analysis of Foreign Trade," Quarterly Journal of Economics, Vol. 47 (May), 493-503.

[36] Lipsey, R. G., 1957, "The Theory of Customs Unions: Trade Diversion and Welfare," Economica, Vol. 24 (February), 40-46. 
[37] Lipsey, R. G., 1960, “The Theory of Customs Unions: a General Survey," Economic Journal, Vol. 70 (September), 496-513.

[38] Lipsey, R. G. and Lancaster, K. J., 1956-1957, "The General Theory of Second Best." Review of Economic Studies, Vol. 24 (1), 11-32.

[39] McKenzie, L. W., 1959, "On the Existence of General Equilibrium for a Competitive Market," Econometrica, Vol. 27 (January), 54-71.

[40] Meade, J. E., 1952, A Geometry of International Trade, London: George Allen and Unwin.

[41] Meade, J. E., 1955a, The Theory of Customs Unions, Amsterdam: North Holland.

[42] Meade, J. E., 1955 b, Trade and Welfare (The Theory of International Economic Policy, Vol. II), Oxford: Oxford University Press.

[43] Mundell, R. A., 1960, "The Pure Theory of International Trade," American Economic Review, Vol. 50 (March), 67-110.

[44] Musgrave, R. A., 1959, The Theory of Public Finance, New York: McGraw-Hill.

[45] Myint, H., 1958, "The Classical Theory of International Trade and the Underdeveloped Countries," Economic Journal, Vol. 68 (June), 317-337.

[46] Negishi, T., 1968, "Protection of the Infant Industry and Dynamic Internal Economies," Economic Record, Vol. 24 (March), 56-57.

[47] Negishi, T., 1963, “On Social Welfare Function," Quarterly Journal of Economics, Vol. 77 (February), 156-158.

[48] Nikaidô, H., 1968, Convex Structures and Economic Theory, New York: Academic Press.

[49] Ohyama, M., 1972, "Domestic Distortions, and the Theory of Tariffs," Keio Economic Studies, Vol. 9 (No. 1), 1-14.

[50] Ohyama, M., 1970, "Tariffs and the Transfer Problem," unpublished.

[51] Ozga, S. A., 1955, "An Essay in the Theory of Tariffs," Journal of Political Economy, Vol. 63 (December), 489-499.

[52] Ray, A., 1970, "On the Infant Industry Argument for Protection and its Policy Implications," unpublished.

[53] Ray, A., 1971, "A General Theorem on Uniform Versus Differentiated Tariff Structure," unpublished.

[54] Samuelson, P. A., 1939, "The Gains from International Trade," Canadian Journal of Economics and Political Science, Vol. 5 (May), 195-205.

[55] Samuelson, P. A., 1950, "Evaluation of Real National Income," Oxford Economic Papers, Vol. 2 (January), 1-29.

[56] Samuelson, P. A., 1952, "The Transfer Problem and Transport Costs: the Terms of Trade when Impediments are Absent," Economic Journal, Vol. 62 (June), 278-304.

[57] Samuelson, P. A., 1954, "The Transfer Problem and Transport Costs, II: Analysis of Effects of Trade Impediments," Economic Journal, Vol. 64 (June), 264-289.

[58] Samuelson, P. A., 1956, "Social Indifference Curves," Quarterly Journal of Economics, Vol. 70 (February), 1-22.

[59] Samuelson, P. A., 1962, "The Gains from International Trade Once Again," Economic Journal, Vol. 72 (December), 820-829.

[60] Scitovsky, T., 1942, "A Reconsideration of the Theory of Tariffs," Review of Economic Studies, Vol. 9 (Summer), 89-110.

[61] Sontheimer, K. V., 1971, "An Existence Theorem for the Second Best," Journal of Economic Theory, Vol. 3 (March), 1-22.

[62] Tan, A. H. H., 1971, "Optimal Trade Policies and Non-Economic Objectives in Models Involving Imported Materials, Inter-Industry Flows and Non-traded Goods," Review of Economic Studies, Vol. 38 (February), 105-111.

[63] Tinbergen, J., 1962, Shaping the World Economy: Suggestions for an International Economic Policy, New York: Twentieth Century Fund. 
[64] Vanek, J., 1965, General Equilibrium of International Discrimination: The Case of Customs Unions, Cambridge, Mass.: Harvard University Press.

[65] Viner, J., 1950, The Customs Union Issue, New York: Carnegie Endowment for International Peace. 